\title{
Morphology engineering of self-assembled porous zinc manganate hexagons for lithium ion storage
}

Cao, Huili; Xiao, Xinxin; Wang, Xinzhen; Liu, Jiurong; Si, Pengchao

Published in:

Electrochimica Acta

Link to article, DOI:

10.1016/j.electacta.2019.135260

Publication date:

2020

Document Version

Peer reviewed version

Link back to DTU Orbit

Citation (APA):

Cao, H., Xiao, X., Wang, X., Liu, J., \& Si, P. (2020). Morphology engineering of self-assembled porous zinc manganate hexagons for lithium ion storage. Electrochimica Acta, 330, [135260].

https://doi.org/10.1016/j.electacta.2019.135260

\section{General rights}

Copyright and moral rights for the publications made accessible in the public portal are retained by the authors and/or other copyright owners and it is a condition of accessing publications that users recognise and abide by the legal requirements associated with these rights.

- Users may download and print one copy of any publication from the public portal for the purpose of private study or research.

- You may not further distribute the material or use it for any profit-making activity or commercial gain

- You may freely distribute the URL identifying the publication in the public portal 


\section{Morphology Engineering of Self-assembled Porous}

\section{Zinc Manganate Hexagons for Lithium Ion Storage}

Huili Cao ${ }^{a, b}$, Xinxin Xiao ${ }^{b}$, Xinzhen Wang ${ }^{c}$, Jiurong Liu ${ }^{* a}$, Pengchao Si*a

${ }^{a}$ Key Laboratory for Liquid-Solid Structural Evolution and Processing of Materials, Ministry of

Education and School of Materials Science and Engineering, Shandong University, Jinan, Shandong 250061, People's Republic of China

${ }^{b}$ Department of Chemistry, Technical University of Denmark, DK-2800 Kongens Lyngby, Denmark

${ }^{c}$ School of Materials Science and Engineering, Shandong University of Science and Technology, Qingdao 266590, China

Corresponding authors: jrliu@sdu.edu.cn (Jiurong Liu); pcsi@sdu.edu.cn (Pengchao Si) 
Abstract: Porous zinc manganate $\left(\mathrm{ZnMn}_{2} \mathrm{O}_{4}\right)$, which is typically fabricated from the decomposition of its carbonates, promises a high-performance anode material for lithium ion batteries (LIBs). Most of porous $\mathrm{ZnMn}_{2} \mathrm{O}_{4}$ in literature presents in sphere morphology. Herein, a unique type of porous $\mathrm{ZnMn}_{2} \mathrm{O}_{4}$ hexagons with a side length of about $2 \mu \mathrm{m}$ and a BET specific surface area of $34.19 \mathrm{~m}^{2} \mathrm{~g}^{-1}$, assembled by ca. $100 \mathrm{~nm}$ nanoparticles, has been successfully fabricated by a solvothermal reaction with subsequent calcination of the self-assembled catenapoly intermediates. The growth mechanism of the solvothermal products has been systematically investigated by adjusting the stoichiometric ratio of oxalic acid, the type of the salt source and acid additive, and the reaction media, resulting in a wide spectrum of morphologies ranging from hexagon, porous sphere, hourglass to belt. The hexagon precursor was calcinated in air to obtain the porous structure, attributed to the space between nanoparticle assemblies. When used for lithium-ion storage, the as-prepared porous $\mathrm{ZnMn}_{2} \mathrm{O}_{4}$ hexagons-based anode exhibits a reversible capacity of $716 \mathrm{mAh} \mathrm{g}^{-1}$ after 200 cycles at $100 \mathrm{~mA} \mathrm{~g}^{-1}$, outperforming the pure porous $\mathrm{Mn}_{2} \mathrm{O}_{3}$ hexagons and the non-porous $\mathrm{ZnMn}_{2} \mathrm{O}_{4}$ hexagons.

Keywords: Zinc manganate; lithium-ion storage; anode materials; solvothermal reaction; hexagons 


\section{Introduction}

Because of the long cycling life, large specific energy, high output voltage and no memory effect, ${ }^{1-4}$ lithium-ion batteries (LIBs) have been widely adopted in a wide range of applications in electric vehicles and consumable electronics. Although considerable trials have paved the way for pursuing LIBs with high power and energy densities, the present batteries still hardly meet all the requirements of ever-growing energy utilization. The challenges lie in the components of LIBs including the cathode, ${ }^{5}$ anode, ${ }^{6}$ and electrolyte, ${ }^{7}$ which are all key factors determining the electrochemical performance. Recently, cathode materials are developing much faster than that on anode for commercial use, while the anode materials are still limited to graphite family due to the cycling stability issue. ${ }^{8-9}$ It is imperative to seek for alternative anode materials with low-cost and high performance. Transition metal oxides (TMOs) are attracting considerable research interests due to their significantly higher theoretical capacities over graphite. Among them, the $\mathrm{AB}_{2} \mathrm{O}_{4}$ spinel structured oxides are demonstrated to display better electrochemical performance than simple TMOs owing to their higher electrochemical activities. ${ }^{10} \mathrm{ZnMn}_{2} \mathrm{O}_{4}$ is drawing increasing attention because i) Mn is cheap and has a relatively low oxidation potential, ii) Zn can react with Li ions to form Li-Zn alloy leading to extra capacity. ${ }^{11-13}$

Large volume changes during charge/discharge processes can damage the anode materials, resulting in cycling degradation. One solution is to fabricate novel nanostructures or porous structures. $\mathrm{ZnMn}_{2} \mathrm{O}_{4}$ (theoretical capacity: $1024 \mathrm{mAh} \mathrm{g}^{-1}$ ) with various morphologies and structures, such as nanoparticles, ${ }^{14-15}$ nanoplates, ${ }^{16}$ porous spheres, ${ }^{12,}{ }^{17-18}$ nano-flowers, ${ }^{19}$ thin films $^{20}$ and nanorods ${ }^{21-22}$ have been reported. The morphology dependent energy storage performance has been widely reported. ${ }^{23-24}$ For example, Chen et al. fabricated porous $\mathrm{ZnMn}_{2} \mathrm{O}_{4}$ 
nanospheres using a sol-gel method registering a reversible capacity of $810 \mathrm{mAh} \mathrm{g}^{-1}$ at a current density of $100 \mathrm{~mA} \mathrm{~g}^{-1}$ after 10 cycles' charge/discharge, over those of nanoparticles (680 $\mathrm{mAh} \mathrm{g}^{-}$ ${ }^{1}$ ). Yuan et al. synthesized three-dimensional porous $\mathrm{ZnMn}_{2} \mathrm{O}_{4}$ thin films on $\mathrm{Ni}$ foams through electrostatic spray deposition, displaying a reversible capacity of $982 \mathrm{mAh} \mathrm{g}^{-1}$ at $400 \mathrm{~mA} \mathrm{~g}^{-1}$ after 100 cycles, in contrast to the capacity of $662 \mathrm{mAh} \mathrm{g}^{-1}$ for the non-porous counterpart. This can be explained by the low charge-transfer impedance of the spinal $\mathrm{ZnMn}_{2} \mathrm{O}_{4}$ and the porous structure, which not only enhances the contact possibility between electrolyte and active materials, but also buffers the volume change during the lithiation/delithiation process.

Most of the reports on porous $\mathrm{ZnMn}_{2} \mathrm{O}_{4}$ rely on the thermal decomposition of metal carbonates. For example, Wang et al. ${ }^{25}$ used a hydrothermal method with urea addition to provide carbonate to form the $\mathrm{Zn}_{x} \mathrm{Mn}_{1-\mathrm{x}} \mathrm{CO}_{3}$ precipitation for porous $\mathrm{ZnMn}_{2} \mathrm{O}_{4}$ microspheres. Chen et al. ${ }^{26}$ fabricated porous $\mathrm{ZnMn}_{2} \mathrm{O}_{4}$ nanospheres derived from the precursor obtained with a microemulsion method adding $\left(\mathrm{NH}_{4}\right) \mathrm{HCO}_{3}$. Zhong et al. ${ }^{27}$ used both of $\left(\mathrm{NH}_{4}\right) \mathrm{HCO}_{3}$ and urea to fabricate the precursor for mesoporous $\mathrm{ZnMn}_{2} \mathrm{O}_{4}$ microspheres through a hydrothermal reaction. The metal carbonates decomposition method leads to limited morphologies of the materials to porous spheres, excepting that a recent research on mesoporous $\mathrm{ZnMn}_{2} \mathrm{O}_{4}$ submicrocubes whose precursor was obtained through a microemulsion process with adding n-hexane, n-pentanol, CTAB and $\left(\mathrm{NH}_{4}\right) \mathrm{HCO}_{3}$ and extended growth time. ${ }^{28}$ Furthermore, template method and the annealing of emerging precursors such as $\mathrm{Zn}-\mathrm{Mn}$ complexes are promising to obtain porous $\mathrm{ZnMn}_{2} \mathrm{O}_{4}$ in various morphologies. For example, Zhang et al. ${ }^{29}$ coated $\mathrm{ZnMn}_{2} \mathrm{O}_{4}$ nanosheets on the surfaces of carbon nanotubes (CNTs). The removal of CNTs by calcination generated porous $\mathrm{ZnMn}_{2} \mathrm{O}_{4}$ hollow nanotubes. Zhu et al. ${ }^{30}$ synthesized porous $\mathrm{ZnMn}_{2} \mathrm{O}_{4}$ micro-belts using a sustainable self-sacrifice biomorphic template. There are several reports on fabricating $\mathrm{ZnMn}_{2} \mathrm{O}_{4}$ through annealing self-assembled polymer 
intermediates with metal ions. For example, Zhang et $\mathrm{al}^{31}$ fabricated hollow microspheres using ethylene glycol additives to form $\mathrm{ZnMn}$-gly-colate-2. Zhang et al. ${ }^{32}$ synthesized $\mathrm{ZnMn}_{2} \mathrm{O}_{4}$ porous nanowires by the calcination of a one-dimensional long chain polymers of (-Zn0.33-Mn0.66-NTA)n formed with the assistance of nitrilotriacetic acid (NTA). The morphology of the product obtained by template method depends on the structure of the template, and the fabrication process generally needs one more step to remove the template. However, the template free method by forming $\mathrm{Zn}-\mathrm{Mn}$ complexes is easy to operate and the versatile metal complexes could enable a wide range of morphologies.

Self-assembled catena-poly ${ }^{33}$, as one kind of polymeric complex bridged by anions, has been barely used as precursors for fabrication of metal oxides. This work aims to fabricate porous $\mathrm{ZnMn}_{2} \mathrm{O}_{4}$ in different morphologies by the calcination of well-controlled catena-poly precursors based on the selection of symmetry molecules and asymmetrical anions. To the best of our knowledge, this is the very first work on reporting porous $\mathrm{ZnMn}_{2} \mathrm{O}_{4}$ in hexagonal morphologies. The porous hexagons exhibit a high BET surface area of $34.19 \mathrm{~m}^{2} \mathrm{~g}^{-1}$ (Table S1). Morphology control from porous hexagons, porous spheres, hourglass to belts of the products can be achieved by carefully altering the usage of solvent and additives. When used as the anode of LIBs, the porous $\mathrm{ZnMn}_{2} \mathrm{O}_{4}$ hexagons exhibit a high capacity of $716 \mathrm{mAh} \mathrm{g}^{-1}$ at $100 \mathrm{~mA} \mathrm{~g}^{-1}$ after cycling 200 times. Impedance study reveals that porous $\mathrm{ZnMn}_{2} \mathrm{O}_{4}$ hexagons benefit from the triple transition metal oxide with lower charge transfer resistance than that of $\mathrm{Mn}_{2} \mathrm{O}_{3}$, and also the porous structure facilitating the diffusion of the electrolyte into the inner part of active materials.

\section{Experimental}

\subsection{Chemicals and Materials.}


Zinc acetate $\left(\mathrm{Zn}\left(\mathrm{CH}_{3} \mathrm{COO}\right)_{2} \cdot 2 \mathrm{H}_{2} \mathrm{O}, 99.0 \%\right)$, oxalic acid $\left(\mathrm{H}_{2} \mathrm{C}_{2} \mathrm{O}_{4}, 99 \%\right)$, manganese acetate $\left(\mathrm{Mn}\left(\mathrm{CH}_{3} \mathrm{COO}\right)_{2} \cdot 4 \mathrm{H}_{2} \mathrm{O}, 99.0 \%\right)$, N,N-dimethylformamide (, 99.0\%), absolute ethyl alcohol, white polyvinylidene fluoride (PVDF $\left(\mathrm{C}_{2} \mathrm{H}_{2} \mathrm{~F}_{2}\right)_{n}$, MW 500 000-700 000) and N-methyl-2pyrrolidone $\left(\mathrm{C}_{5} \mathrm{H}_{9} \mathrm{NO}, \mathrm{NMP}\right)$ were purchased from Sinopharm Chemical Reagent Co., Ltd, China. Carbon black, Li foil and Celgard 2300 were obtained from Hefei Kejing Material Technology Co., Ltd, China. $\mathrm{LiPF}_{6}$ dissolved in ethylene carbonate, dimethyl carbonate, and ethylene methyl carbonate in a volumetric ratio of 1:1:1 was purchased from Shenzhen Biyuan Technology Co., Ltd, China. All the chemicals of analytical grade were used as-received without further purification.

\subsection{Synthesis of porous hexagon $\mathrm{ZnMn}_{2} \mathrm{O}_{4}$.}

In a typical process, $2 \mathrm{mmol} \mathrm{Mn}\left(\mathrm{CH}_{3} \mathrm{COO}\right)_{2} \cdot 4 \mathrm{H}_{2} \mathrm{O}, 1 \mathrm{mmol} \mathrm{Zn}\left(\mathrm{CH}_{3} \mathrm{COO}\right)_{2} \cdot 2 \mathrm{H}_{2} \mathrm{O}$ and $9 \mathrm{mmol}$ oxalic acid were dispersed in a mixed solution consisting of $20 \mathrm{ml} \mathrm{DMF}$ and $30 \mathrm{ml}$ absolute alcohol at room temperature with two-hour stirring. The aged solution was sealed in a Teflon-lined stainless autoclave and heated at $170{ }^{\circ} \mathrm{C}$ for $6 \mathrm{~h}$. The resultant precipitate was centrifuged and washed with ethanol for several times, allowed to be dry in an oven at $60^{\circ} \mathrm{C}$ for $12 \mathrm{~h}$. The precursor existing in a form of white powders was treated at $600{ }^{\circ} \mathrm{C}$ for $2 \mathrm{~h}$ in air, and the brown-powderlike final product, porous hexagon $\mathrm{ZnMn}_{2} \mathrm{O}_{4}$, was obtained. For comparison study, $\mathrm{ZnO}$ and $\mathrm{Mn}_{2} \mathrm{O}_{3}$ were also prepared following the similar route, while without the addition of either $\mathrm{Mn}\left(\mathrm{CH}_{3} \mathrm{COO}\right)_{2} \bullet 4 \mathrm{H}_{2} \mathrm{O}$ or $\mathrm{Zn}\left(\mathrm{CH}_{3} \mathrm{COO}\right)_{2} \bullet 2 \mathrm{H}_{2} \mathrm{O}$, respectively.

\subsection{Materials Characterization.}

X-ray powder diffraction patterns of the samples were obtained using a Rigaku D/Max-RC X-ray diffractometer with a Ni filtered $\mathrm{Cu} K \alpha$ radiation $(\lambda=0.1542 \mathrm{~nm}, \mathrm{~V}=40 \mathrm{kV}, \mathrm{I}=50 \mathrm{~mA})$ in the 
range of $10-90^{\circ} \mathrm{C}$ at a scanning rate of $4{ }^{\circ} \mathrm{C} \mathrm{min}^{-1}$. The microstructure of the final product was examined via a JSM-6700F field emission scanning electron microscope (FE-SEM, accelerating voltage: $20 \mathrm{kV}$, electric current: $1.0 \times 10^{-10} \mathrm{~A}$ ) equipped with energy-dispersive $\mathrm{X}$-ray spectroscopy (EDX), and a JEOL JEM-2100 transmission electron microscope (TEM, $200 \mathrm{kV}$ ). X-ray photoelectron spectroscopy (XPS) was performed with a Kratos Analytical spectrometer using an $\mathrm{Al} \mathrm{K} \alpha(\mathrm{h} v=1486.6 \mathrm{eV})$ radiation as the excitation source under an anode voltage of 12 $\mathrm{kV}$ and an emission current of $10 \mathrm{~mA}$. The thermogravimetric analysis (TGA) was carried out via a Mettler-Toledo TGA/SDTA851e Thermo Analyzer in the temperature range from room temperature (R.T.) to $800{ }^{\circ} \mathrm{C}$ with an elevating rate of $10{ }^{\circ} \mathrm{C} \mathrm{min}^{-1}$ in air. $\mathrm{N}_{2}$ adsorption/desorption measurement was performed by an ASAP 2020 instrument and Brunauer-Emmet-Teller (BET) methods were used to calculate the surface area.

\subsection{Electrochemical measurements.}

To fabricate the working electrode, the active material (porous hexagon $\mathrm{ZnMn}_{2} \mathrm{O}_{4}$ ), carbon black and PVDF with a weight ratio of 7:2:1 were mixed in NMP to form a homogenous slurry, which was coated on a copper foil substrate and dried in a vacuum oven at $120^{\circ} \mathrm{C}$ for $12 \mathrm{~h}$. When the oven was cooled down to room temperature, the copper foil was cut into discs with a diameter of $14 \mathrm{~mm}$. On each disc, the total mass loading, weighed by a microbalance (FA2004, Soptop, China), of the slurry and the active material on the copper foil is 3.3-3.6 $\mathrm{mg}$ and $2.3-2.5 \mathrm{mg}$, respectively. The performance of the cell was evaluated galvanostatically in a voltage range of $0.02-3 \mathrm{~V}$ at various current densities using a LAND CT2001A battery test system. Electrochemical impedance spectroscopy (EIS) was tested on an Ivium potentiostat from a frequency range of $0.01 \mathrm{~Hz}-100$ $\mathrm{kHz}$ at the open circuit potential. Cyclic voltammetry (CV) measurement was conducted in a potential range of 0.02 to $3 \mathrm{~V}$ at a scan rate of $0.3 \mathrm{mV} \mathrm{s}^{-1}$. 


\section{Results and discussion}

\subsection{Morphology and structures of mesoporous $\mathrm{ZnMn}_{2} \mathrm{O}_{4}$ hexagons.}

Mesoporous $\mathrm{ZnMn}_{2} \mathrm{O}_{4}$ hexagons are prepared by a self-assembly process and subsequent thermal decomposition, as shown in Fig. 1. When $\mathrm{Mn}^{2+}, \mathrm{Zn}^{2+}$ and oxalic acid are added into a N,Ndimethylformaminde (DMF)/ethanol solution, metal ions interact with the aldehyde (-CHO) groups from DMF and carboxyl groups (-COOH) of oxalic acid, resulting in plate-like catena-poly precipitate (step I). The catena-poly undergoes reorganization under hydrothermal conditions to form layered hexagons (step II). The mesoporous structure is finally obtained by an annealing treatment (step III) to remove the DMF and oxalic molecules.

The morphology and phase property of the product obtained in each step are investigated. As shown in Fig. 1(a), the morphology of the sedimentation before solvothermal process is bulky with uniform dispersion. It clearly shows that the bulky sedimentation is constructed with nanoflakes with a length of ca. $2 \mu \mathrm{m}$. XRD patterns of the sedimentation fit well with that of catena-poly (COD: 96-221-1889 for Mn and 96-223-1719 for Zn) (Fig. 1 (b)). ${ }^{34-35}$ DMF and oxalic acid are believed to serve as the surfactants to make the sedimentation uniformly dispersed, in a way that two DMF molecules and one oxalic acid molecule coordinate to one divalent metal ion. FTIR is also used to confirm the structure of catena-ploy (Fig. 1(c)). The strong bands at 1616.30 and $1652.95 \mathrm{~cm}^{-1}$ can be assigned to the symmetric and antisymmetric $\mathrm{C}=\mathrm{O}$ stretching modes of oxalic acid and DMF molecules. ${ }^{36-37}$ Double bands at 1313.48 and $1386.78 \mathrm{~cm}^{-1}$ are attributed to the OC-O stretching modes from oxalic acid, with the O-C-O bending mode located at $796.58 \mathrm{~cm}^{-1}$. The typical $\mathrm{CH}_{3}$ symmetric stretching and $\mathrm{C}-\mathrm{H}$ stretching mode for DMF are at around $2937.50 \mathrm{~cm}^{-}$ ${ }^{1,38}$ as well as the $\mathrm{CH}_{3}$ asymmetric deformation mode at $1431 \mathrm{~cm}^{-1}$ and $\mathrm{CH}_{3}$ rocking mode at 1093 and $1063 \mathrm{~cm}^{-1} .{ }^{39}$ The typical N-C-H bending mode from DMF is located at $1386.78 \mathrm{~cm}^{-1}$, with 
$\mathrm{O}=\mathrm{C}-\mathrm{N}$ stretching at $659 \mathrm{~cm}^{-1} .{ }^{40}$ The peaks at the wavenumber range between 3200 and $3500 \mathrm{~cm}^{-}$

${ }^{1}$ belong to the $\mathrm{O}-\mathrm{H}$ stretching vibration due to traces of water. ${ }^{41}$
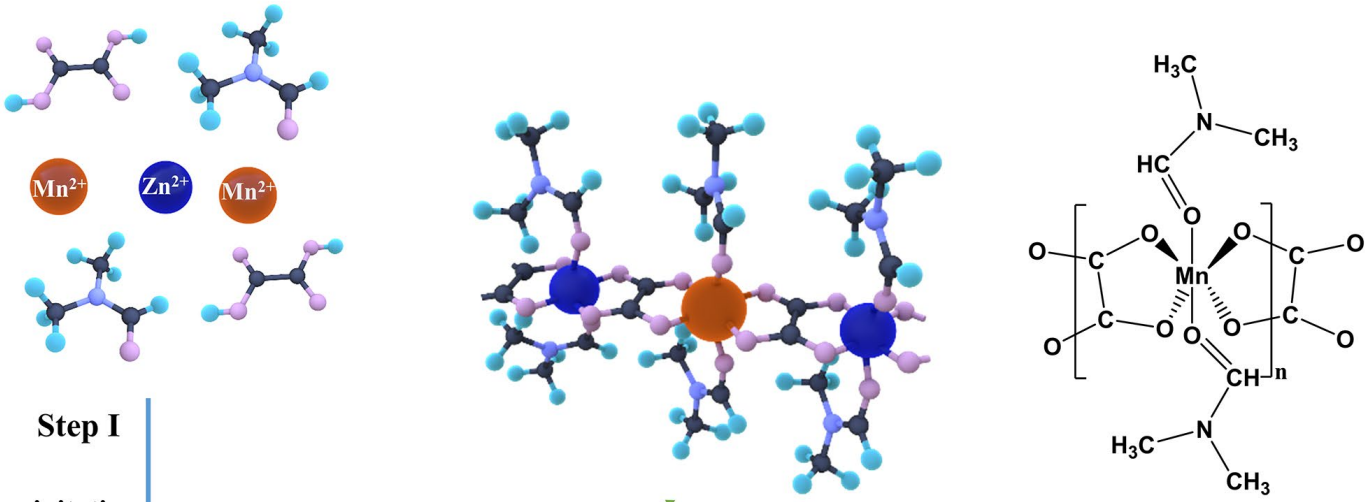

Precipitation
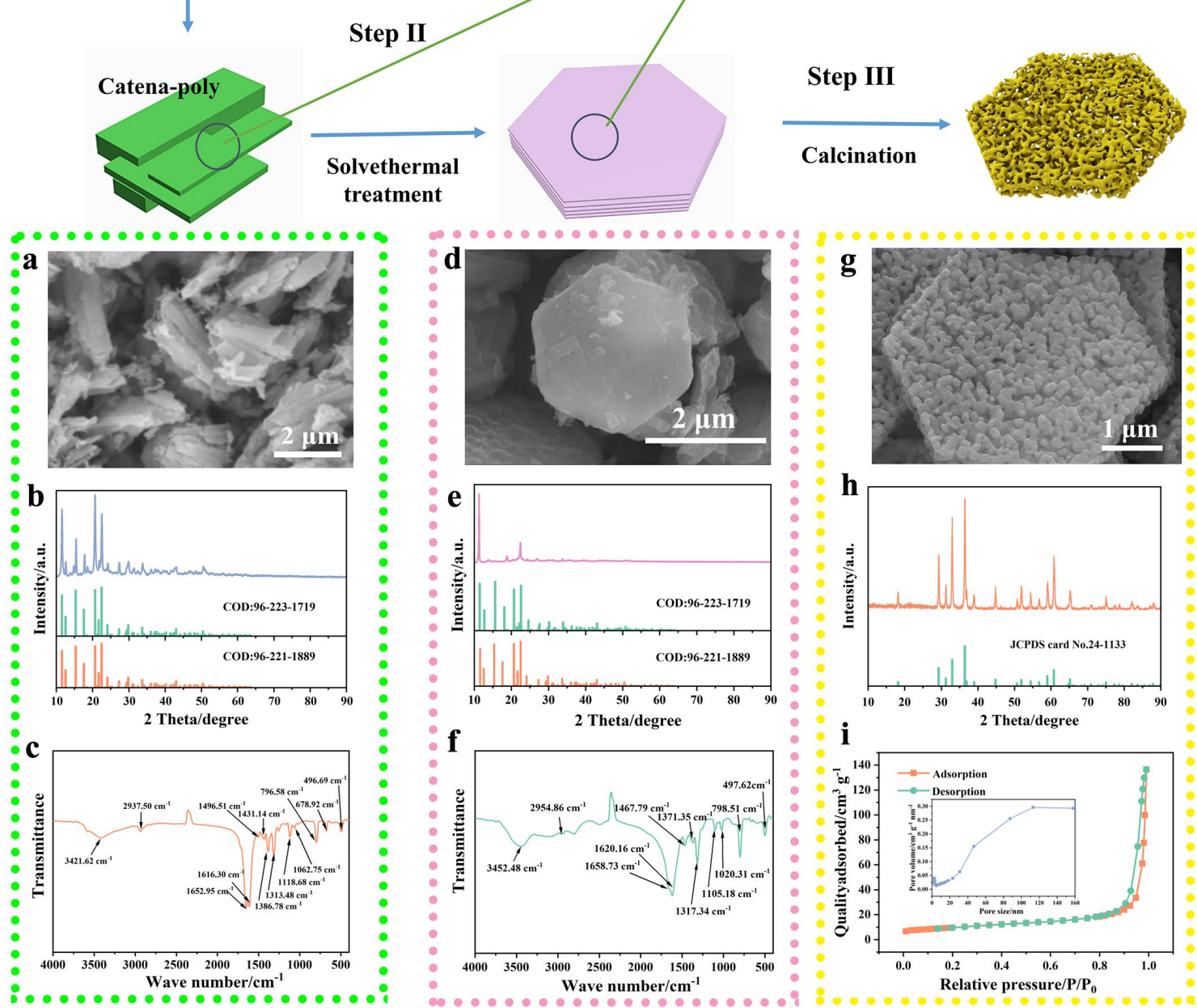

Fig. 1. Schematic illustration of the synthesis process of porous $\mathrm{ZnMn}_{2} \mathrm{O}_{4}$ hexagons and the corresponding SEM images and XRD patterns of the product obtained from each step ((a) and (b): the first step; (d) and (e): the second step; $(g)$ and (h): the third step). FTIR spectra of the precursors in the first step (c), and the second step (f); $N_{2}$ adsorption-desorption isotherm and pore size distribution (PSD) (i) of the as-obtained porous $\mathrm{ZnMn}_{2} \mathrm{O}_{4}$ sample. 
During the hydrothermal treatment (high pressure and high temperature), the sedimentations transform their structure to hexagons, as shown in Fig. 1(d). In low magnification, the products are all hexagons with an edge size of 1-3 $\mu$ m confirmed by SEM (Fig. S1(a)). The side-view SEM image (inset of Fig. S1(a)) indicates that hexagons are assembled by nanoflakes. The surface of a single hexagon shows that the precursor is solid without porous structure. The crystalline phase and component of the precursor are examined by XRD. As shown in Fig. 1(e), the diffraction peaks of the sample match well with the catena-poly. After the solvothermal treatment, the peak intensities at around $10^{\circ}$ becomes stronger, which is likely due to either the larger lattice space caused by forming sheet structure, or the anisotropy favored orientation. ${ }^{42}$ It means the solvothermal process is crucial for the formation of hexagons. FTIR is also used to confirm the above statements. As displayed in Fig. 1(f), the typical peaks for oxalic acid and DMF can be observed in the FTIR curve after solvothermal process. It means the products exist as catena-ploy, corresponding well with the XRD results. FESEM EDS (Fig. S1) shows that the elemental oxygen (white), zinc (red), manganese (green) in a selected area are homogeneously distributed all over the hexagons, and the percentage ratio of $\mathrm{Zn}$ and $\mathrm{Mn}$ is about 1:2. There are no clear boundaries between $\mathrm{Zn}$ and $\mathrm{Mn}$ catena-poly.

To find out the proper calcination temperature, thermogravimetric analysis (TGA) is used to investigate the thermal degradation behaviors of hexagonal catena-poly precursors obtained by the solvothermal process. As shown in Fig. S2, the initial weight has decreased by $49.9 \%$ at $270{ }^{\circ} \mathrm{C}$ due to the evaporation of water and DMF molecules ${ }^{25}$, followed by the removal of oxalic acid and oxidation of Mn species by ca. $23.9 \%$ when heated up to $300^{\circ} \mathrm{C}$. The total weight loss by $72.6 \%$ corresponds to the transition from catena-poly to porous $\mathrm{ZnMn}_{2} \mathrm{O}_{4}$. When the hexagonal precursor is annealed at a temperature of $300{ }^{\circ} \mathrm{C}$, the product shows non-porous structure and low 
crystallinity, which is examined by XRD and SEM, as shown in Fig. S3. In the XRD patterns in Fig. S3(a), the product tends to be amorphous, and the weak peaks can be indexed to $\mathrm{ZnMn}_{2} \mathrm{O}_{4}$ (JCPDS No. 24-1133). It indicates that the product has been transformed into $\mathrm{ZnMn}_{2} \mathrm{O}_{4}$ at $300{ }^{\circ} \mathrm{C}$. As for the data from TGA, when the temperature exceeds $300{ }^{\circ} \mathrm{C}$, no more weight loss occurs, indicating the precursors are all transferred into $\mathrm{ZnMn}_{2} \mathrm{O}_{4}$. The SEM image in Fig. S3(b) shows the surface of the hexagon is rough and solid, in the same size as the structure in the precursors. The final product is treated under $600{ }^{\circ} \mathrm{C}$ to obtain the porous structure shown in Fig. $1(\mathrm{~g})$. It can be found the porous hexagon is an assembly of nanoparticles in ca. $100 \mathrm{~nm}$. The XRD patterns (Fig. 1(h)) of the porous material show the typical crystalline feature of tetragonal $\mathrm{ZnMn}_{2} \mathrm{O}_{4}$ (JCPDS No. 24-1133, $\mathrm{a}=\mathrm{b}=5.7204 \AA, \mathrm{c}=9.245 \AA, \alpha=\beta=\gamma=90^{\circ}$ ) with a space group of $\mathrm{I}_{1} / \mathrm{amd}$. The lattice parameters of the product are calculated to be $\mathrm{a}=\mathrm{b}=5.7624 \AA, \mathrm{c}=9.2686 \AA, \alpha=\beta=\gamma$ $=90^{\circ}$, respectively. No peaks of any other phases can be detected, indicative of the high purity of $\mathrm{ZnMn}_{2} \mathrm{O}_{4}$. The formation of the porous structure is mainly due to the decomposition of the catenapoly by evaporating of DMF and release $\mathrm{CO}_{2}$ from oxalic acid, resulting in a high specific surface area. ${ }^{43}$ Nitrogen adsorption-desorption isotherms are recorded to characterize the specific surface area and the pore structure of the porous hexagonal $\mathrm{ZnMn}_{2} \mathrm{O}_{4}$, as displayed in Fig. 1(i). It indicates the specific BET surface area is about $34.19 \mathrm{~m}^{2} \mathrm{~g}^{-1}$, with a wide pore size distribution from 60 to $160 \mathrm{~nm}$ caused by the space of nanoparticles. Small pores $(2-6 \mathrm{~nm})$ are likely attributed to the pores on the nanoparticles. The BET surface area in some published articles using $\mathrm{ZnMn}_{2} \mathrm{O}_{4}$ as lithium ion batteries are collected in Table S1. For example, Wang et al. synthesized porous $\mathrm{ZnMn}_{2} \mathrm{O}_{4}$ microspheres with a surface area of $17.7 \mathrm{~m}^{2} \mathrm{~g}^{-1}$ and the pore size in a range of 45-90 $\mathrm{nm}$, which can enhance the diffusion of electrolyte to active materials. ${ }^{25}$ Chen et al. synthesized mesoporous $\mathrm{ZnMn}_{2} \mathrm{O}_{4}$ submicrobuces with a surface area of $22.92 \mathrm{~m}^{2} \mathrm{~g}^{-1}$ and a pore size in range 
of 2 to $8 \mathrm{~nm}$, which was shown to buffer the large volume change during the $\mathrm{Li}^{+}$ insertion/extraction. ${ }^{42}$ Comparing with the published articles, this porous hexagonal $\mathrm{ZnMn}_{2} \mathrm{O}_{4}$ has both large and small pores.

The TEM images further confirm that the obtained sample displays hexagon structure with a size of ca. $3 \mu \mathrm{m}$ (Fig. 2(a)). In the HRTEM image (Fig. 2(b)), the porous structure can be clearly observed. The size of the nanoparticle assembled hexagon is confirmed again to be about $100 \mathrm{~nm}$ (Fig. 2(c)). The corresponding selected area electron diffraction pattern (Fig. 1(g)) shows multicrystal diffraction rings, implying that the porous $\mathrm{ZnMn}_{2} \mathrm{O}_{4}$ hexagons are multi-crystal materials, ${ }^{44}$ which is caused by the nanoparticles assembling. The pores between nanoparticles can be clearly observed with radius in the range $50-80 \mathrm{~nm}$. The porous structure in size of 2 to $10 \mathrm{~nm}$ on the single particles could also be observed clearly in Fig. 2(d), in good agreement with the observation from the pore size distribution (Fig. 1(i)). In addition, the typical lattice fringe spacing on one nanoparticle is well-defined and measured to be $0.48 \mathrm{~nm}$, corresponding to the (101) crystal plane of $\mathrm{ZnMn}_{2} \mathrm{O}_{4}$ (Fig. 2(d)).

To ascertain the chemical composition and electronic state of porous $\mathrm{ZnMn}_{2} \mathrm{O}_{4}$ hexagons product, XPS measurement was conducted. From the survey scan spectrum (Fig. 2(e)), four kinds of elements ( $\mathrm{Zn}, \mathrm{Mn}, \mathrm{O}$ and $\mathrm{C}$ ) are present in the products. The existence of the $\mathrm{C} 1 \mathrm{~s}$ peak is likely due to carbon contamination. The peaks at 654.5 and 642.7 eV (in Fig. 2(f)) are attributed to Mn 2p1/2 and Mn 2p3/2, respectively, which are assigned to $\mathrm{Mn}^{3+} \cdot{ }^{45}$ In Fig. 2(g), the two peaks located at 1021.6 and $1044.5 \mathrm{eV}$ are assigned to $\mathrm{Zn} 2 \mathrm{p} 1 / 2$ and $\mathrm{Zn} 2 \mathrm{p} 3 / 2$ from $\mathrm{Zn}^{2+},{ }^{46}$ respectively. Using Gaussian fitting method, O 1s spectrum (Fig. 2(h)) can be divided into three peaks. The peak at $530.1 \mathrm{eV}$ is the typical lattice oxygen in $\mathrm{AB}_{2} \mathrm{O}_{4}$ spinel structured oxides, ${ }^{47}$ and the other two weak 
peaks at 532.3 and $531.3 \mathrm{eV}$ can be attributed to the $\mathrm{C}-\mathrm{O}$ bonds form surface adsorbed carbon dioxide and the hydroxyl groups from absorbing water, respectively. ${ }^{48}$
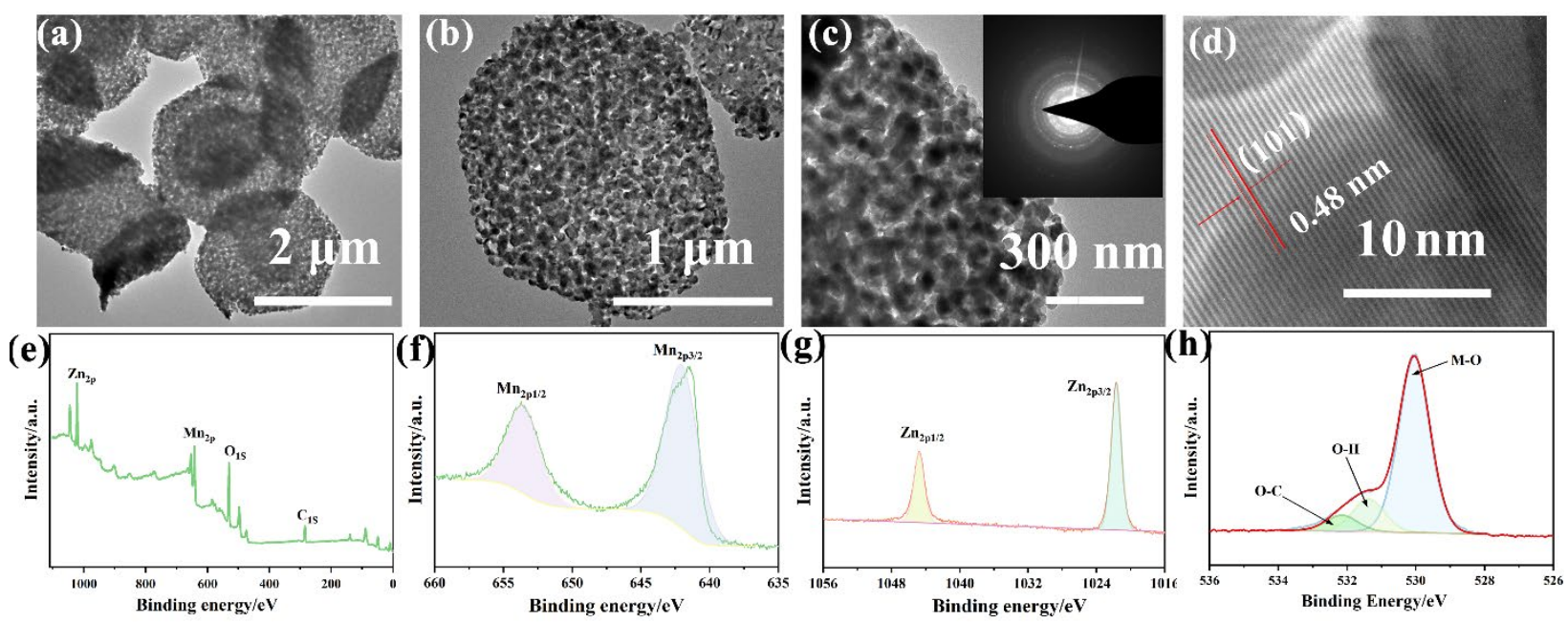

Fig. 2 TEM images (a)-(d) of porous hexagon $\mathrm{ZnMn}_{2} \mathrm{O}_{4}$ at different magnifications. XPS survey spectrum (e), Mn $2 p(f), \mathrm{Zn} 2 p(g)$ and $\mathrm{O} 1 \mathrm{~s}(\mathrm{~h})$ spectrum of the porous hexagon $\mathrm{ZnMn}_{2} \mathrm{O}_{4}$. The inset of $(c)$ is the selected area electron diffraction (SAED) pattern.

\subsection{Evaluation of governing parameters during the formation of $\mathrm{ZnMn}_{2} \mathrm{O}_{4}$.}

A series of experiments, such as varying the amount and type of acid, the solution and salt types, are carried out to investigate their effects on the formation of the hexagons.

The role of oxalic acid is examined. Without addition of oxalic acid, the metal ions would be homogenously surrounded by DMF molecules. As shown in Fig. 3(a) and (e), the products after calcination are only in one morphology of porous microspheres with size ranging from 1 to $5 \mu \mathrm{m}$. It indicates that the DMF helps to form porous structures. Increasing the oxalic acid concentration, the products tend to form hexagons. Due to the metal ions can form catena-poly with the presence of both oxalic acid and DMF, the addition of $3 \mathrm{mmol}$ oxalic acid leads to flake products (Fig. 3(b, f)), however with a widely distributed size range. When using $6 \mathrm{mmol}$ oxalic acid (Fig. 3(c)), the resulting hexagons are in a relative narrow size range from 1 to $10 \mu \mathrm{m}$. However, some of the flakes are still layered (Fig. $3(\mathrm{~g})$ ). 9 mmol oxalic acid is chosen as the optimal concentration, 
leading to most of the flakes are hexagons (Fig. 3(d)). The size of porous hexagons is in a range of 1-3 $\mu \mathrm{m}$, with a thickness of about $500 \mathrm{~nm}$ (Fig. 3(h)). It can be concluded that oxalic acid helps to form more edges. In order to evaluate the role of carboxyl group of oxalic acid, citric acid is used during the formation process, considering that each citric acid molecule has three carboxyl groups. The resulting products present flake structure (Fig. S4(a)). However, the nanoparticles on the surface of the flakes (Fig. S4(b)) are randomly distributed.

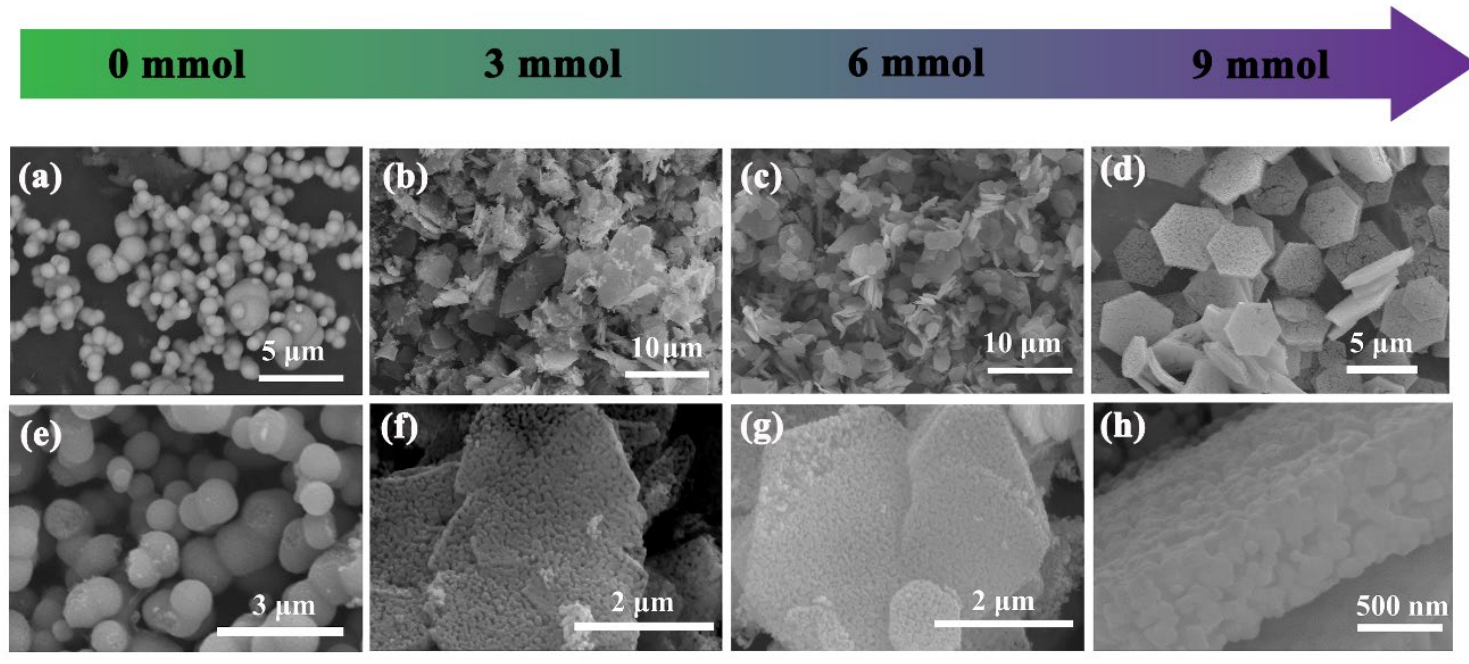

Fig. 3 SEM images of the $\mathrm{ZnMn}_{2} \mathrm{O}_{4}$ prepared with $0(a, e), 3(b, f), 6(c, g)$ and 9 mmol $(d, h)$ oxalic acid. The role of the solvent for the solvothermal process is also studied. As above mentioned, the existence of DMF is one of the governing factors to form catena-poly. When using pure ethanol as the solvent, the metal ions coordinate with both oxygen atoms of the carboxyl group. The morphology of the precursor obtained with pure DMF is mainly belt with a width of $100 \mathrm{~nm}$ (Fig. 4(a)). The hexagon structure can also be found but with non-uniform edge size. According to XRD in Fig. S5(a), the precursor is not pure catena-poly (COD: 96-221-1889 for Mn and 96-223-1719 for $\mathrm{Zn}$ ), indicating the catena-poly formation requires the existence of ethanol. After calcination in air, the organic solvent is assembled by nanoparticles with the same size as found in the precursor. The hexagons turn to be porous structure with the same size of hexagons obtained by 
mixed solvent, but the length of each edge is not uniform. When the solvent is changed into pure ethanol, the precursor presents hourglass-shape like structure (Fig. 4(b)), with lengths ranging from 5 to10 $\mu \mathrm{m}$. The hourglass has nanowire-like ends. XRD (Fig. S5(b)) is used to investigate the component of the precursor. The precipitation is attributed to manganese oxalate (COD: 00-0010160) and zinc oxalate (COD: 00-037-0718). After annealed in air, the oxalates transform into metal oxides by removing carbon dioxide, resulting in $\mathrm{ZnMn}_{2} \mathrm{O}_{4}$ composed of nanoparticles, as displayed in Fig. 4(d). It's likely that ethanol helps to form homogenous hexagons with edges in the same size.

The oxalic acid is the bridge for forming the polymeric complex, which leads to the microscale edges during the reaction, and the DMF provides the branches on the catena-poly, contributing to the sheet structure formation. Zinc and manganese ion both can form the pure Zn catena-poly or Mn catena-poly, with the similar structure to Zn-Mn catena-poly. The knowledge is transferrable as a general strategy to fabricate different metal oxide hexagons, such as $\mathrm{ZnO}$ and $\mathrm{Mn}_{2} \mathrm{O}_{3}$ hexagons. As shown in Fig. 5(a) and (c), the products fabricated using pure Zn salts show a hexagon flake structure with the size from 1 to $5 \mu \mathrm{m}$. In higher magnification of SEM (Fig. 5(c)), the surfaces of the hexagons can be clearly observed. They are all nanoparticles with a particle size much larger than that of the product synthesized via the mixed salts. The phase of the products is hexagonal $\mathrm{ZnO}\left(\mathrm{COD}\right.$ No. 96-230-0113, $\left.\mathrm{a}=\mathrm{b}=3.2490 \AA, \mathrm{c}=5.2050 \AA, \alpha=\beta=90^{\circ}, \gamma=120^{\circ}\right)$ (Fig. S6(a)), which has a space group of P63mc. No peaks of any other phases can be detected, illustrating the high purity of $\mathrm{ZnO}$. The morphology of the product fabricated by pure Mn salt (Fig. 5(b) and (d)) is also hexagonal structure with much smaller nanoparticles than porous $\mathrm{ZnMn}_{2} \mathrm{O}_{4}$. In the XRD patterns image (Fig. S6(b)), all diffraction peaks can be well indexed to orthorhombic $\mathrm{Mn}_{2} \mathrm{O}_{3}\left(\right.$ ICDD No. 01-073-1826, $\mathrm{a}=9.4118, \mathrm{~b}=9.4177 \AA, \mathrm{c}=9.4233 \AA, \alpha=\beta=\gamma=90^{\circ}$ ), which 
has a space group of Pbca. No peaks of any other phases can be detected, illustrating the high purity of $\mathrm{Mn}_{2} \mathrm{O}_{3}$. Therefore, the fabrication process of porous hexagons could be used for synthesizing porous pure $\mathrm{ZnO}$ and pure $\mathrm{Mn}_{2} \mathrm{O}_{3}$ hexagons.
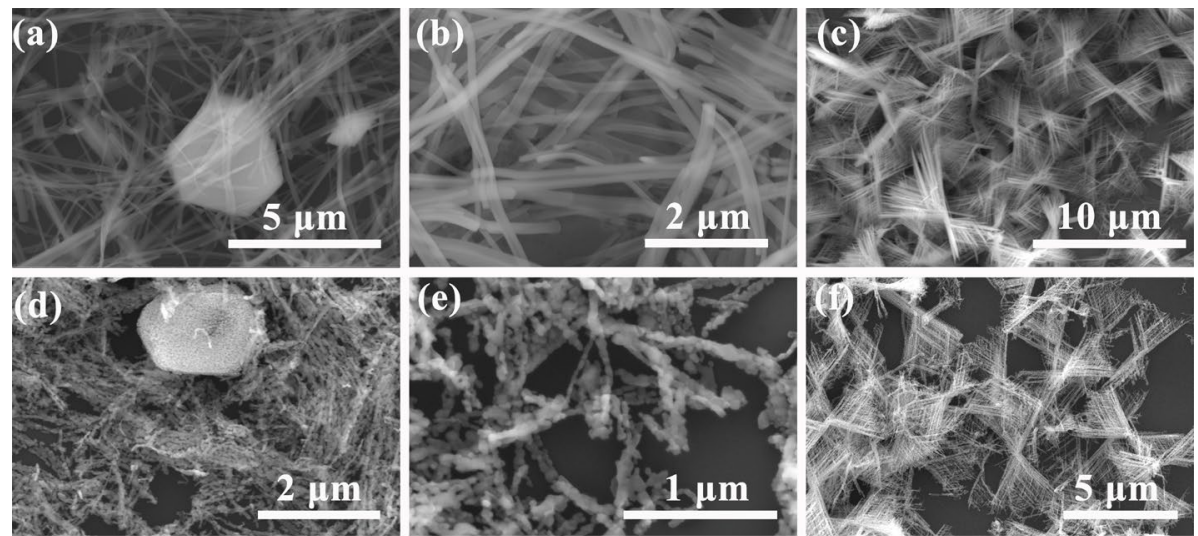

Fig. 4 SEM images of the precursors ( $a, b)$ obtained by adding pure DMF solvent, precursors (c) obtained by adding pure ethanol. The corresponding $\mathrm{ZnMn}_{2} \mathrm{O}_{4}$ prepared by calcination of precursors obtained by $(d, e)$ adding pure DMF and (f) pure ethanol.
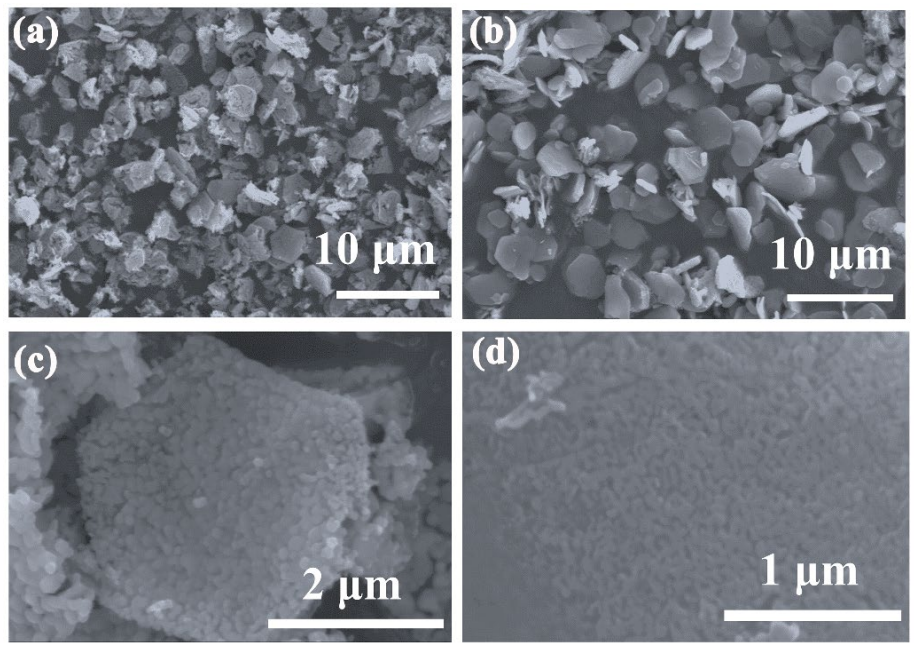

Fig. 5 SEM images of porous $\mathrm{ZnO}(a, c)$ and $\mathrm{Mn}_{2} \mathrm{O}_{3}(b, d)$.

These results prove that the acid is one of the key factors for the formation of the flake structure, and the presence of oxalic acid and DMF can facilitate the formation of hexagons. ${ }^{49-51}$ Even changing the salt to the pure one, the hexagons can also be obtained. The summarized mechanisms for synthesizing different morphologies are displayed in Fig. 6. It's likely that the symmetric structure of oxalic acid helps to form micro-structured catena-ploys with edges, rather than 
spheres. The usage of the mixed-solvent of DMF and ethanol is also essential to form uniform hexagons with a high yield.
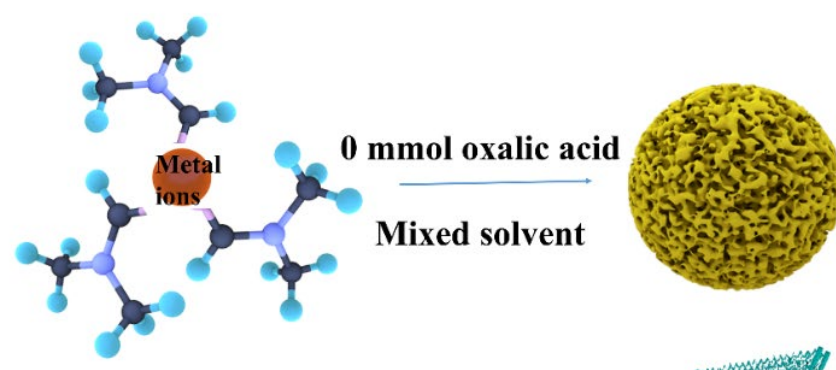

(a)
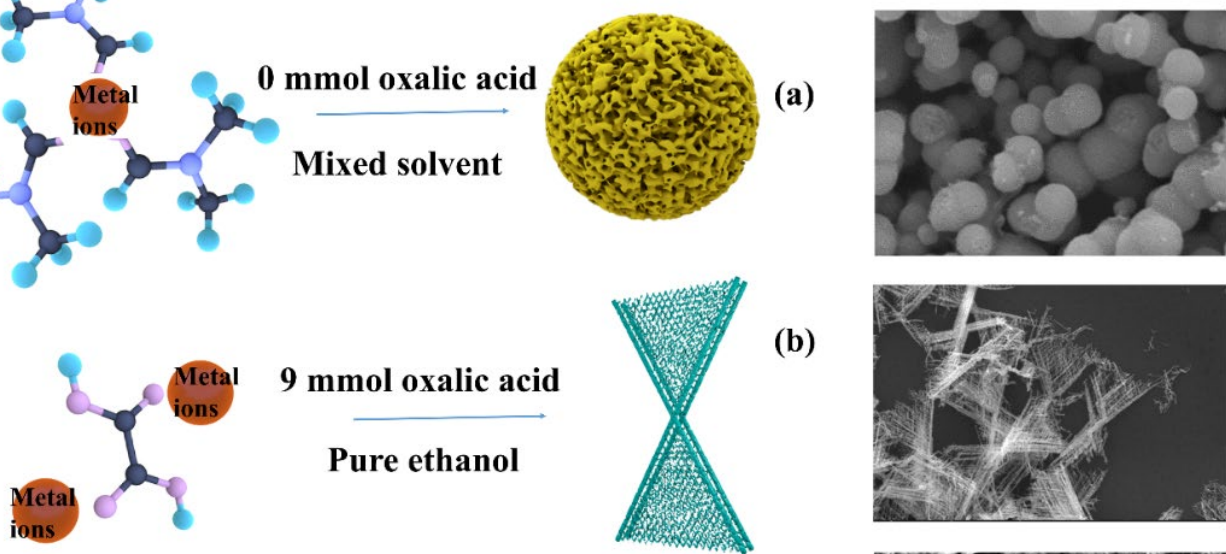

9 mmol oxalic acid

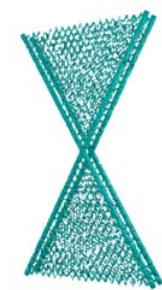

(b)

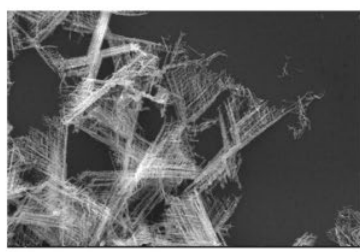

Pure ethanol
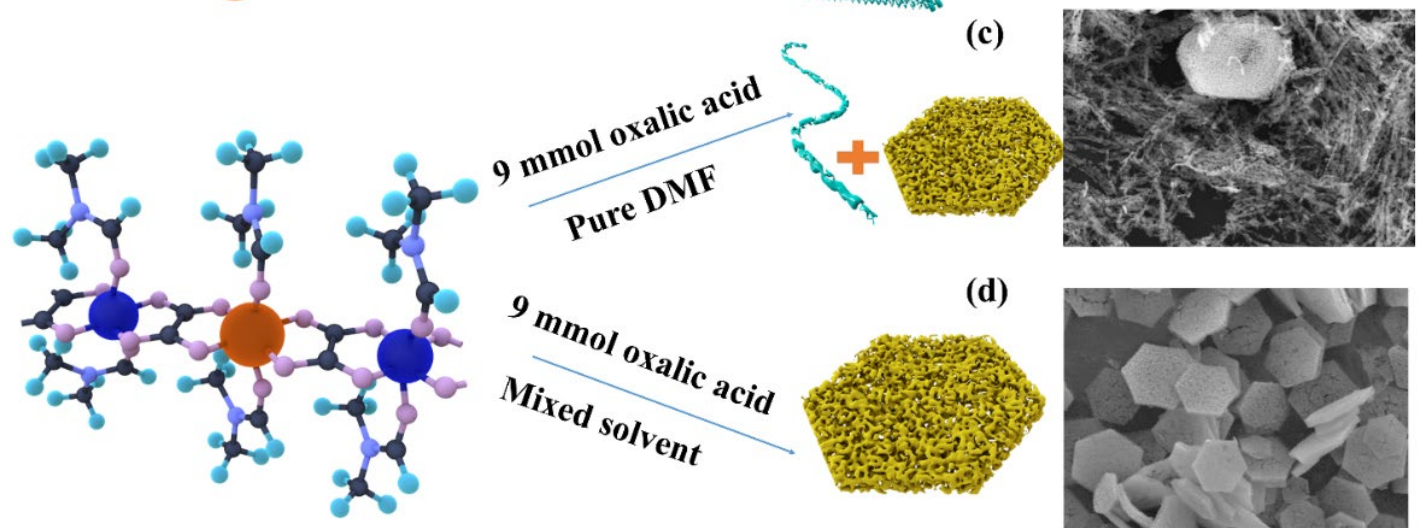

9 mmoloxalic acid
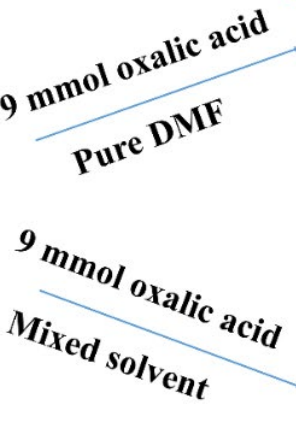

(d)

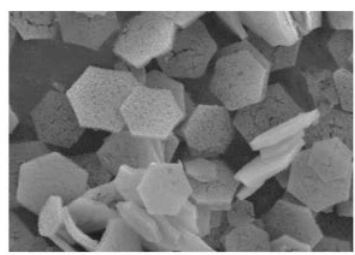

Fig. 6 Schematic illustration of the formation process of microspheres (a), hourglass-shaped structures (b), belts (c) and hexagons (d), and corresponding SEM images.

\subsection{Electrochemical performance of porous hexagon $\mathrm{ZnMn}_{2} \mathrm{O}_{4}$.}

The electrochemical behavior of the as-prepared porous $\mathrm{ZnMn}_{2} \mathrm{O}_{4}$ hexagons serving as anodes in LIBs, has been compared to those of solid $\mathrm{ZnMn}_{2} \mathrm{O}_{4}$ hexagons and porous $\mathrm{Mn}_{2} \mathrm{O}_{3}$ hexagons. As shown in Fig. 7(a), in the first cathodic scan, three peaks are observed at approximately 1.1, 0.75 and $0.2 \mathrm{~V}$, which can be assigned to the reduction of $\mathrm{Mn}^{3+}$ to $\mathrm{Mn}^{2+}$, formation of SEI film and the reduction of $\mathrm{Mn}^{2+}$ and $\mathrm{Zn}^{2+}$ to $\mathrm{Mn}^{0}$ and $\mathrm{Zn}^{0}$, respectively, companied by the formation of $\mathrm{LiZn}^{52}$ The initial anodic scan shows an intensive peak at $1.1 \mathrm{~V}$ and a broad one at $1.5 \mathrm{~V}$, ascribed to the 
oxidation of $\mathrm{Mn} 0$ to $\mathrm{Mn}^{2+}$ and $\mathrm{Zn}^{0}$ to $\mathrm{Zn}^{2+}$, respectively. In the following cycles, the cathodic peaks at 1.1 and $0.7 \mathrm{~V}$ disappear, implying that the transformation of $\mathrm{Mn}^{3+}$ to $\mathrm{Mn}^{2+}$ and the SEI film formation are irreversible. ${ }^{14,53}$ The porous $\mathrm{ZnMn}_{2} \mathrm{O}_{4}$ hexagons are charged and discharged at a current density of $100 \mathrm{~mA} \mathrm{~g}^{-1}$ between $0.01-3 \mathrm{~V}$ (Fig. 7(b)). In the first discharge profile of the porous $\mathrm{ZnMn}_{2} \mathrm{O}_{4}$ hexagons exhibits two obvious platforms at about 1.1, 0.7 and $0.2 \mathrm{~V}$. The platform at $1.1 \mathrm{~V}$ corresponds to the reduction of $\mathrm{Mn}^{3+}$ to $\mathrm{Mn}^{2+}, 54$ and the 0.7 and $0.2 \mathrm{~V}$ ones are from the reversible reaction of the electrolyte and the formation of SEI layer, and the formation of $\mathrm{Zn}^{0}$, LiZn and $\mathrm{Mn}^{0}$, respectively. The first discharge specific capacity of the porous $\mathrm{ZnMn}_{2} \mathrm{O}_{4}$ is estimated to be $1039 \mathrm{mAh} \mathrm{g}^{-1}$, slightly higher than the theoretical capacity of $\mathrm{ZnMn}_{2} \mathrm{O}_{4}(1024 \mathrm{mAh}$ $\left.\mathrm{g}^{-1}\right),{ }^{54}$ which can be attributed to the decomposition of electrolyte and the formation of SEI films. ${ }^{55}$ While in the charge curve, there are two plateaus at ca. 1.1 and $1.5 \mathrm{~V}$ corresponding to the oxidation of $\mathrm{Mn}$ to $\mathrm{Mn}^{2+}$ and $\mathrm{Zn}$ to $\mathrm{Zn}^{2+}$, respectively. ${ }^{54}$ The overall charging capacity is about $582.4 \mathrm{mAh}$ $\mathrm{g}^{-1}$, and the initial coulombic efficiency (CE) is ca. $56 \%$, The initial CE of ca. $56 \%$ can be explained by the irreversible formation of solid electrolyte interphase (SEI), a process that the electrolyte is reduced to form a film on the surface of the active material. ${ }^{56-57}$ The second discharge/charge cycle shows good capacity retention due to the stabilized reaction between the electrolyte and the porous structure of the electrode. The galvanostatic discharge/charge process is in good agreement to the CV curves, and the reactions can be written as below: ${ }^{58}$

Initial discharge:

$$
\mathrm{ZnMn}_{2} \mathrm{O}_{4}+9 \mathrm{Li}^{+}+9 e^{-} \rightarrow \mathrm{LiZn}+2 \mathrm{Mn}+4 \mathrm{Li}_{2} \mathrm{O}(1)
$$

Following reversible reactions:

$$
Z n+L^{+}+e^{-} \leftrightarrow \operatorname{LiZn}(2)
$$




$$
\begin{aligned}
& \mathrm{Mn}+\mathrm{Li}_{2} \mathrm{O} \leftrightarrow \mathrm{MnO}+2 \mathrm{Li}^{+}+2 e^{-} \\
& \mathrm{Zn}+\mathrm{Li}_{2} \mathrm{O} \leftrightarrow \mathrm{ZnO}+2 \mathrm{Li}^{+}+2 e^{-}
\end{aligned}
$$

In comparison, the charge and discharge curves of porous $\mathrm{Mn}_{2} \mathrm{O}_{3}$ and solid $\mathrm{ZnMn}_{2} \mathrm{O}_{4}$ are shown in Fig. 7(c) and 7(d), respectively. The platforms of porous $\mathrm{Mn}_{2} \mathrm{O}_{3}$ during discharge curve are located at ca. 1.1, 0.7 and $0.2 \mathrm{~V}$, corresponding the reduction of $\mathrm{Mn}^{3+}$ to $\mathrm{Mn}^{2+}$, SEI film formation and reduction of $\mathrm{Mn}^{2+}$ to $\mathrm{Mn}^{0}$, respectively. While there is only one platform during charge process associated to the oxidation of $\mathrm{Mn}^{0}$ to $\mathrm{Mn}^{2+}$. As for solid $\mathrm{ZnMn}_{2} \mathrm{O}_{4}$, the platform during discharge could be observed at the same potential with porous $\mathrm{ZnMn}_{2} \mathrm{O}_{4}$. Two platforms are expected during charging, but only one is observed because the solid material cannot be fully used during charge and discharge process. The initial CEs of porous $\mathrm{Mn}_{2} \mathrm{O}_{3}$ and solid $\mathrm{ZnMn}_{2} \mathrm{O}_{4}$ are $50.2 \%$ and $44.8 \%$, respectively, lower than that of porous $\mathrm{ZnMn}_{2} \mathrm{O}_{4}(56 \%)$.

The electron transfer resistance on the electrolyte/active material interfaces is investigated by electrochemical impedance spectroscopy (EIS) measurements for half cells, which is conducted at an open circuit voltage. The Nyquist plots of porous $\mathrm{Mn}_{2} \mathrm{O}_{3}$, and solid and porous $\mathrm{ZnMn}_{2} \mathrm{O}_{4}$ hexagons before and after cycling for 200 cycles are presented in Fig. 7(e) and (f). The plots display a small semicircle at the high-frequency region and a straight line at the low frequency region. The diameter of the semicircle reveals the value of the charge-transfer impedance $\left(\mathrm{R}_{\mathrm{ct}}\right){ }^{59}$ As shown in Fig. 7(e), the porous $\mathrm{ZnMn}_{2} \mathrm{O}_{4}$ anode owns a lower $\mathrm{R}_{\mathrm{ct}}(80 \Omega)$ than those of the $\mathrm{Mn}_{2} \mathrm{O}_{3}$ $(230 \Omega)$ and solid $\mathrm{ZnMn}_{2} \mathrm{O}_{4}$ anode $(120 \Omega)$ before cycling, indicating the electronic conductivity of the porous $\mathrm{ZnMn}_{2} \mathrm{O}_{4}$ is better than the other two anode. In addition, the straight line is attributed to the Warburg impedance, which could reflect rate of intercalation/deintercalation of $\mathrm{Li}^{+}$by diffusion coefficient $\left(\mathrm{D}_{\mathrm{Li}+}\right)$. The linear fitting of the Warburg impedance with the real part $Z^{\prime}$ is 
shown in Fig.7g, allowing the estimation of the Warburg coefficient $\left(A_{w}\right)$, which is the diffusion coefficient of ions in solution, and $\mathrm{D}_{\mathrm{Li}}$ based on the following equations: ${ }^{46,60}$

$$
\begin{aligned}
& \mathrm{Z}^{\prime}=\mathrm{Rs}+\mathrm{Rct}+\mathrm{A}_{w} w^{-\frac{1}{2}}(5) \\
& D_{L i^{+}}=\left[\frac{V_{m}}{F A A_{w}}\left(-\frac{d E}{d x}\right)\right]^{2}(6)
\end{aligned}
$$

Where $V_{m}$ is the molar volume $\left(\mathrm{cm}^{3} \mathrm{~mol}^{-1}\right), \mathrm{F}$ is the Faraday constant $\left(96485 \mathrm{~s} \mathrm{~A} \mathrm{~mol}^{-1}\right)$, $\mathrm{A}$ is the surface area of the electrode $\left(\mathrm{cm}^{2}\right)$, and $(\mathrm{dE}) /(\mathrm{dx})$ is the slope of the open circuit potential and the Li ion concentration. ${ }^{61}$ Eq. 6 indicates that $\mathrm{D}_{\mathrm{Li}+}$ is mainly determined by $\left(1 / \mathrm{A}_{\mathrm{w}}\right)^{2}$ and a small $\mathrm{A}_{\mathrm{w}}$ represents a large $\mathrm{D}_{\mathrm{Li}^{+} .}$As shown in table 1 . The fresh solid $\mathrm{ZnMn}_{2} \mathrm{O}_{4}$ has the lowest $\mathrm{A}_{\mathrm{W}}\left(48 \Omega \mathrm{s}^{-}\right.$ $\left.{ }^{1 / 2}\right)$ than those of porous $\mathrm{ZnMn}_{2} \mathrm{O}_{4}\left(61 \Omega \mathrm{s}^{-1 / 2}\right)$ and porous $\mathrm{Mn}_{2} \mathrm{O}_{3}\left(84 \Omega \mathrm{s}^{-1 / 2}\right)$, implying the best ion conductivity and highest $\mathrm{Li}^{+}$diffusion coefficient. However, after cycling test, porous $\mathrm{ZnMn}_{2} \mathrm{O}_{4}$ has the lower $\mathrm{A}_{\mathrm{w}}$ (Fig. $7 \mathrm{~h}, 29 \Omega \mathrm{s}^{-1 / 2}$ ) than those of solid $\mathrm{ZnMn}_{2} \mathrm{O}_{4}\left(981 \Omega \mathrm{s}^{-1 / 2}\right)$ and porous $\mathrm{Mn}_{2} \mathrm{O}_{3}$ (1182 $\Omega \mathrm{s}^{-1 / 2}$ ). Additionally, the $\mathrm{R}_{\mathrm{ct}}$ of $\mathrm{ZnMn}_{2} \mathrm{O}_{4}$ slightly increases to $93 \Omega$, while considerably increases to $800 \Omega$ and $1000 \Omega$ for the porous $\mathrm{Mn}_{2} \mathrm{O}_{3}$ and the solid $\mathrm{ZnMn}_{2} \mathrm{O}_{4}$, respectively. It reveals that the as-prepared solid and porous $\mathrm{ZnMn}_{2} \mathrm{O}_{4}$ hexagons have better conductivity than that of the porous $\mathrm{Mn}_{2} \mathrm{O}_{3}$ due to the spinel structure. In total, the electronic conductivity and ion conductivity of the porous $\mathrm{ZnMn}_{2} \mathrm{O}_{4}$ are all the best after 200 cycles testing, mainly due to the porous structure could buffer the volume change during the repetitive charge and discharge process and the hexagon structure could be maintained. 
Table 1 EIS parameters of the anode electrode before and after cycling test.

\begin{tabular}{l|ccc|ccc}
\hline & \multicolumn{3}{|c|}{ Fresh electrode } & \multicolumn{3}{c}{ After cycling } \\
\hline Electrode & Rs & Rct & $\mathrm{Aw}\left(\Omega \mathrm{s}^{-}\right.$ & Rs & Rct & $\mathrm{Aw}\left(\Omega \mathrm{s}^{-}\right.$ \\
Porous $\mathrm{ZnMn}_{2} \mathrm{O}_{4}$ & $(\Omega)$ & $(\Omega)$ & $1 / 2)$ & $(\Omega)$ & $(\Omega)$ & $1 / 2)$ \\
Solid $\mathrm{ZnMn}_{2} \mathrm{O}_{4}$ & 2.6 & 80 & 61 & 21 & 93 & 29 \\
Porous $\mathrm{Mn}_{2} \mathrm{O}_{3}$ & 2.9 & 120 & 48 & 7 & 800 & 981 \\
\hline
\end{tabular}

The cycling stability of as-prepared products is also studied. Fig. 7(i) presents the cycling performances and coulombic efficiency (CE) of the $\mathrm{ZnMn}_{2} \mathrm{O}_{4}$ and $\mathrm{Mn}_{2} \mathrm{O}_{3}$ materials at $100 \mathrm{~mA} \mathrm{~g}^{-}$ 1. The porous $\mathrm{ZnMn}_{2} \mathrm{O}_{4}$ delivers a stable reversible capacity of $716 \mathrm{mAh} \mathrm{g}^{-1}$ after 200 cycles (corresponding to an energy density of ca. $1064 \mathrm{Wh} \mathrm{kg}^{-1}$, normalized to the weight of active materials). The $\mathrm{CE}$ of $\mathrm{ZnMn}_{2} \mathrm{O}_{4}$ quickly reaches $91 \%$ in the third cycle, which remains more than $95 \%$ in the subsequent cycles. The morphology of porous $\mathrm{ZnMn}_{2} \mathrm{O}_{4}$ hexagons after 200 cycles was investigated by SEM. Although it's difficult to recognize the detailed morphology of the active materials that are mixed with PVDF binder and carbon black (Fig. S7), there are visible integrate hexagons (indicated by arrows) with an edge size of ca. $2 \mu \mathrm{m}$. It means that the integrity of the morphology during the charge and discharge is likely maintained even after 200 cycles. It means that the integrity of the morphology during the charge and discharge is likely maintained even after 200 cycles. For $\mathrm{Mn}_{2} \mathrm{O}_{3}$ samples, the first discharge capacity reaches $1196.6 \mathrm{mAh} \mathrm{g}^{-1}$, much higher than that of the $\mathrm{ZnMn}_{2} \mathrm{O}_{4}$, but the charge capacity is only about $639.2 \mathrm{mAh} \mathrm{g}^{-1}$. After 10 cycles' charge/discharge, the CE just stays at ca. 95\%. In addition, the reversible capacity of the asprepared $\mathrm{ZnMn}_{2} \mathrm{O}_{4}\left(716 \mathrm{mAh} \mathrm{g}^{-1}\right)$ is much higher than that of the pure $\mathrm{Mn}_{2} \mathrm{O}_{3}\left(183 \mathrm{mAh} \mathrm{g}^{-1}\right)$ after 200 cycles at the same current density of $100 \mathrm{~mA} \mathrm{~g}^{-1}$. Moreover, the solid $\mathrm{ZnMn}_{2} \mathrm{O}_{4}$ prepared by calcination at $300{ }^{\circ} \mathrm{C}$ in air maintains a reversible capacity of $336 \mathrm{mAh} \mathrm{g}^{-1}$ after 200 cycles at 100 $\mathrm{mA} \mathrm{g}^{-1}$. Its initial discharge capacity is $1278 \mathrm{mAh} \mathrm{g}^{-1}$, much higher than that of porous $\mathrm{ZnMn}_{2} \mathrm{O}_{4}$, but the initial charge capacity quickly drops to $642 \mathrm{mAh} \mathrm{g}^{-1}$. Moreover, after 80 cycles, the CE of 
the solid $\mathrm{ZnMn}_{2} \mathrm{O}_{4}$ stabilized at $99.2 \%$. Interestingly, there is an obvious increase in the cycling curve of $\mathrm{ZnMn}_{2} \mathrm{O}_{4}$ and $\mathrm{Mn}_{2} \mathrm{O}_{3}$, a common phenomenon for the TMO electrodes, ${ }^{62-63}$ which is due to the activation process of the electrode materials. The electrochemical performance in terms of capacity and cycling performance of the proposed porous $\mathrm{ZnMn}_{2} \mathrm{O}_{4}$ hexagons is better than most of reported $\mathrm{ZnMn}_{2} \mathrm{O}_{4}$ materials and some of single metal oxides, such as $\mathrm{MnO}$ and $\mathrm{FeO}$ (Table S1). For example, the pure $\mathrm{ZnMn}_{2} \mathrm{O}_{4}$ microspheres fabricated via a mixed solvothermal method exhibits $602 \mathrm{mAh} \mathrm{g}^{-1}$ after 100 cycles at the $100 \mathrm{~mA} \mathrm{~g}^{-1} .{ }^{64}$ The reversible capacity of flowerlike $\mathrm{ZnMn}_{2} \mathrm{O}_{4}$ microspheres assembled with porous nanosheets fabricated by solvothermal process reaches $662 \mathrm{mAh} \mathrm{g}^{-1}$ after 120 cycles at the same current density. ${ }^{65}$ And the porous $\mathrm{ZnMn}_{2} \mathrm{O}_{4}$ hexagons is also better than particle materials. Particle materials tend to aggregate, which may result in poor long-term stability issue ${ }^{66}$ While the porous hexagons own high porosity, which not only help to increase the contact between the electrode and electrolyte, but also shorten the diffusion length of electrons and $\mathrm{Li}$ ions. In addition, the pores on hexagons can accommodate the volume expansion to maintain the integration of the active materials. This is confirmed by the comparison of the lithium ion storage performance of porous hexagon $\mathrm{ZnMn}_{2} \mathrm{O}_{4}$ with the ones in literature (Table S1). In summary, the porous hexagon structure can effectively improve the electrochemical performance of the materials by buffering the volume expansion during the reactions. The high specific surface area improves the connection between the electrolyte and the electrode, and the thin flake built by nanoparticles can effectively avoid aggregation during the reaction process. Furthermore, the spinel $\mathrm{ZnMn}_{2} \mathrm{O}_{4}$ has better performance than the pure transition metal oxides as observed in the lower $\mathrm{R}_{\mathrm{ct}}$ in the $\mathrm{ZnMn}_{2} \mathrm{O}_{4}$ than that for $\mathrm{Mn}_{2} \mathrm{O}_{3}$.

The rate properties tested by the various current densities (from 100 to $800 \mathrm{~mA} \mathrm{~g}^{-1}$ ) of porous $\mathrm{ZnMn}_{2} \mathrm{O}_{4}$ hexagons, solid $\mathrm{ZnMn}_{2} \mathrm{O}_{4}$ hexagons and porous $\mathrm{Mn}_{2} \mathrm{O}_{3}$ are shown in Fig. S8. The porous 
$\mathrm{ZnMn}_{2} \mathrm{O}_{4}$ delivers a reversible capacity of $480 \mathrm{mAh} \mathrm{g}^{-1}$ at $100 \mathrm{~mA} \mathrm{~g}^{-1}, 365 \mathrm{mAh} \mathrm{g}^{-1}$ at $200 \mathrm{~mA} \mathrm{~g}^{-}$ ${ }^{1}, 283 \mathrm{mAh} \mathrm{g}^{-1}$ at $400 \mathrm{~mA} \mathrm{~g}^{-1}, 213 \mathrm{mAh} \mathrm{g}^{-1}$ at $800 \mathrm{~mA} \mathrm{~g}^{-1}$, and finally back to $430 \mathrm{mAh} \mathrm{g}^{-1}$ at 100 $\mathrm{mA} \mathrm{g}^{-1}$, subsequently. At a high current density, the porous $\mathrm{Mn}_{2} \mathrm{O}_{3}$ delivers nearly the same capacity with porous $\mathrm{ZnMn}_{2} \mathrm{O}_{4}$. For example, the porous $\mathrm{Mn}_{2} \mathrm{O}_{3}$ has a reversible capacity of 210 $\mathrm{mAh} \mathrm{g}^{-1}$ at current density of $800 \mathrm{~mA} \mathrm{~g}^{-1}$. However, when the current density increases to $100 \mathrm{~mA}$ g-1, porous $\mathrm{Mn}_{2} \mathrm{O}_{3}$ would deliver a lower capacity than porous $\mathrm{ZnMn}_{2} \mathrm{O}_{4}$. It is mainly because that zinc oxide could contribute to the overall capacity during charge and discharge due to the sluggish formation of LiZn alloy, which doesn't contribute greatly when charged/discharged at high current densities. For example, Jing et al. ${ }^{67}$ fabricated $\mathrm{ZnO}$ nanorods which deliver $47 \mathrm{mAh} \mathrm{g}^{-1}$ at current density of $800 \mathrm{~mA} \mathrm{~g}^{-1}$. Park et al. ${ }^{68}$ synthesized $\mathrm{ZnO}$ sphere which deliver $75 \mathrm{mAh} \mathrm{g}^{-1}$ at current density of $500 \mathrm{~mA} \mathrm{~g}^{-1}$. Therefore, there will be less difference for porous $\mathrm{ZnMn}_{2} \mathrm{O}_{4}$ and porous $\mathrm{Mn}_{2} \mathrm{O}_{3}$ at high current densities. However, the solid $\mathrm{ZnMn}_{2} \mathrm{O}_{4}$ delivers much lower capacities, which is only $43 \mathrm{mAh} \mathrm{g}^{-1}$ at $800 \mathrm{~mA} \mathrm{~g}^{-1}$. It indicates that the porous structure could effectively increase the reaction rate of the active materials. When reset to $100 \mathrm{~mA} \mathrm{~g}^{-1}$, the porous $\mathrm{ZnMn}_{2} \mathrm{O}_{4}$, porous $\mathrm{Mn}_{3} \mathrm{O}_{4}$ and solid $\mathrm{ZnMn}_{2} \mathrm{O}_{4}$ reserve their initial capacities, which are 420 (40.4\%), 360 (29.8\%) and $270(21.1 \%) \mathrm{mAh} \mathrm{g}^{-1}$, respectively. The porous $\mathrm{ZnMn}_{2} \mathrm{O}_{4}$ shows the best retention ratio after the high current charge/discharge process. 
(a)

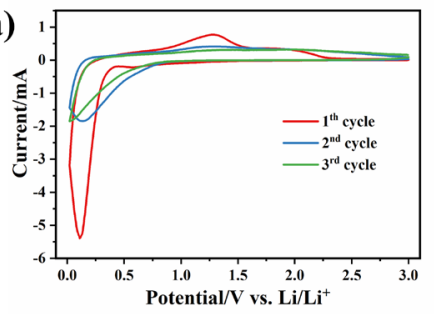

(d)
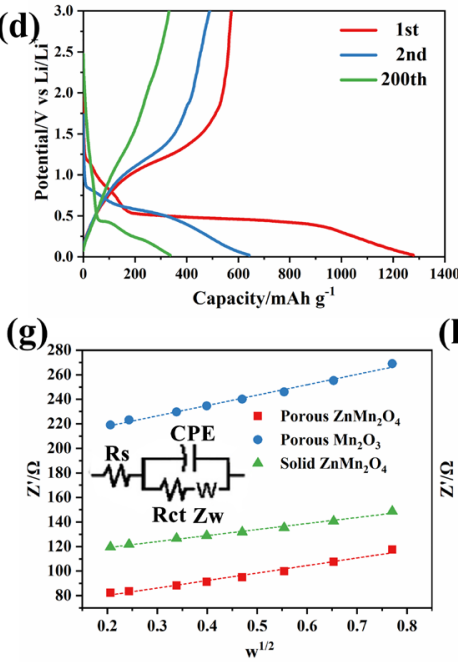

(b)

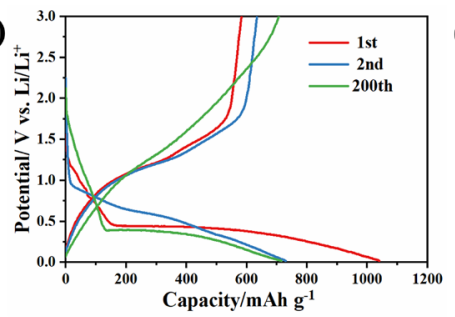

(e)

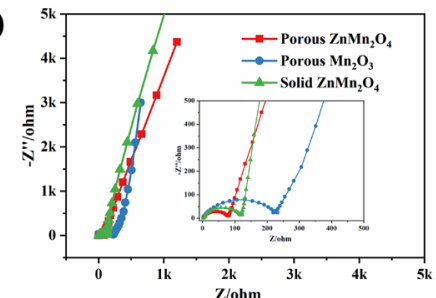

(c)

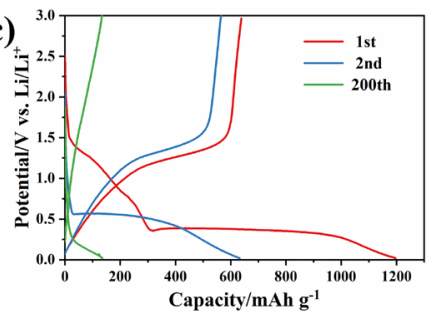

(f)

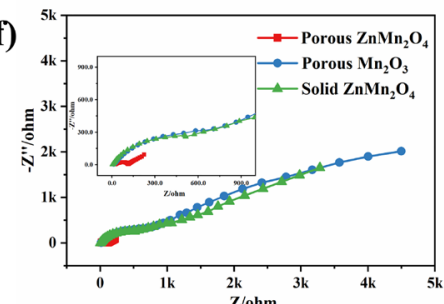

(h)
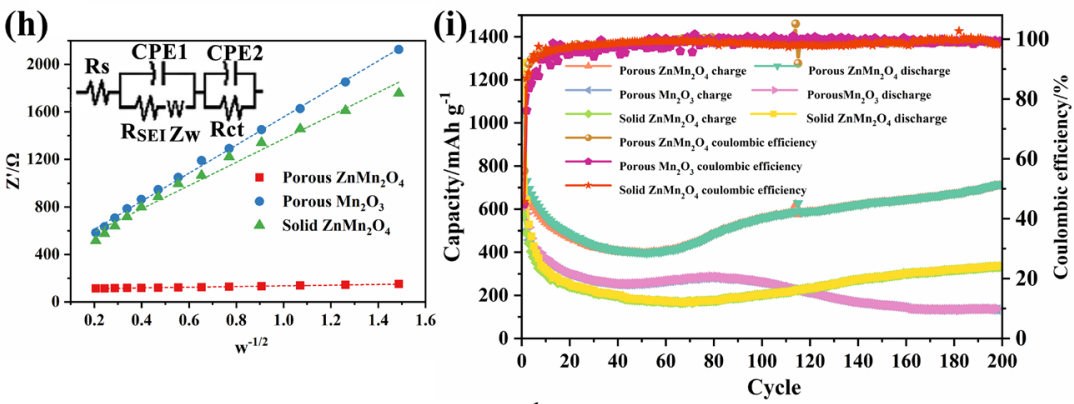

Fig. $7 \mathrm{CV}$ curves of $\mathrm{ZnMn}_{2} \mathrm{O}_{4}$ hexagons at a scan rate of $0.3 \mathrm{mV} \mathrm{s}^{-1}($ a); Galvanostatic discharge/charge curves of the 1st, $2 \mathrm{nd}$, and 200th cycles of porous $\mathrm{ZnMn}_{2} \mathrm{O}_{4}$ hexagons (b), porous $\mathrm{Mn}_{3} \mathrm{O}_{4}$ (c) and solid $\mathrm{ZnMn}_{2} \mathrm{O}_{4}$ (d) at $100 \mathrm{~mA} \mathrm{~g}^{-1}$; Nyquist plots of porous $\mathrm{Mn}_{2} \mathrm{O}_{3}$ and solid and porous $\mathrm{ZnMn}_{2} \mathrm{O}_{4}$ hexagons before (e) and after (f) 200 testing cycles. Linear fitting of the square root of Warburg impedance with real part Z' obtained for the Nyquist plot of $\mathrm{ZnMn}_{2} \mathrm{O}_{4}$ hexagons before ( $g$ ) and after (h) cycling. Comparison of charge-discharge cycling performances and coulombic efficiency of the battery anodes based on porous $\mathrm{ZnMn}_{2} \mathrm{O}_{4}$, solid $\mathrm{ZnMn}_{2} \mathrm{O}_{4}$ and porous $\mathrm{Mn}_{2} \mathrm{O}_{3}$ hexagons (i) at $100 \mathrm{~mA} \mathrm{~g}^{-1}$. Inset of (g) and (h) are the equivalent circuits.

\section{Conclusions}

In summary, the porous $\mathrm{ZnMn}_{2} \mathrm{O}_{4}$ hexagons consisting of porous nanoparticles have been fabricated by solvothermal synthesis followed with calcination. The formation of hexagon structure is significantly affected by the type of acid and the solvent used during solvothermal process. The knowledge on rational control the morphology of the porous $\mathrm{ZnMn}_{2} \mathrm{O}_{4}$ gained herein can be transferred to other TMOs for functional material design. When used as the electrode active materials of lithium ion batteries, the porous $\mathrm{ZnMn}_{2} \mathrm{O}_{4}$ hexagons exhibited better capacitance retention capability and long cycling performance, compared to the pure $\mathrm{Mn}_{2} \mathrm{O}_{3}$ and the solid 
$\mathrm{ZnMn}_{2} \mathrm{O}_{4}$. This is mainly attributed to the porous structure, which facilitates the diffusion of the $\mathrm{Li}^{+}$ions and the reaction with the materials, and the lower charge-transfer impedance.

\section{Acknowledgements}

The authors acknowledge the financial support from the National Natural Science Foundation of China (No. 51572157). This work was also sponsored by research projects from Shandong Provincial Science and Technology Major (2018JMRH0211), the Fundamental Research Funds of Shandong University (2017JC042 and 2017JC010). The sponsorship of a H. C. Ørsted COFUND Scholarship to X. X. and a China Scholarship Council for a PhD scholarship (No. 201706220078) to H. C. is gratefully acknowledged. The authors also thank Susanne Mossin for modifying the manuscript.

\section{Associated Content}

Supporting Information

Additional information and figures including SEM images, EDX mapping and TGA curve of the $\mathrm{ZnMn}_{2} \mathrm{O}_{4}$ hexagons precursors, SEM images and XRD patterns of the solid $\mathrm{ZnMn}_{2} \mathrm{O}_{4}$ hexagons; XRD patterns of the $\mathrm{ZnMn}_{2} \mathrm{O}_{4}$ obtained by using pure solvent and pure salt source; SEM image of the porous $\mathrm{ZnMn}_{2} \mathrm{O}_{4}$ after cycling, and the rate capability curves of the porous $\mathrm{ZnMn}_{2} \mathrm{O}_{4}, \mathrm{Mn}_{2} \mathrm{O}_{3}$ and solid $\mathrm{ZnMn}_{2} \mathrm{O}_{4}$; The comparison table of the proposed $\mathrm{ZnMn}_{2} \mathrm{O}_{4}$ materials with those in literature displaying different morphologies. 


\section{References}

1. Wu, Q.; Liu, J.; Yuan, C.; Li, Q.; Wang, H. G., Nitrogen-doped 3D flower-like carbon materials derived from polyimide as high-performance anode materials for lithium-ion batteries. Appl. Surf. Sci., 425 (2017), pp 1082-1088.

2. $\quad$ Kang, K.; Meng, Y. S.; Bréger, J.; Grey, C. P.; Ceder, G., Electrodes with high power and high capacity for rechargeable lithium batteries. Science, 311 (2006), pp 977-80.

3. Kasavajjula, U.; Wang, C.; Appleby, A. J., Nano- and bulk-silicon-based insertion anodes for lithium-ion secondary cells. J. Power Sources, 163 (2007), pp 1003-1039.

4. Zhou, G.; Wang, D.-W.; Shan, X.; Li, N.; Li, F.; Cheng, H.-M., Hollow carbon cage with nanocapsules of graphitic shell/nickel core as an anode material for high rate lithium ion batteries. J. Mater. Chem., 22 (2012), pp 11252-11256.

5. Yamada, A.; Chung, S. C.; Hinokuma, K., Optimized $\mathrm{LiFePO}_{4}$ for Lithium Battery Cathodes. J. Electrochem. Soc. India, 148 (2001), pp 224-229.

6. Wu, Z. S.; Ren, W.; Wen, L.; Gao, L.; Zhao, J.; Chen, Z.; Zhou, G.; Li, F.; Cheng, H. M., Graphene Anchored with $\mathrm{Co}_{3} \mathrm{O}_{4}$ Nanoparticles as Anode of Lithium Ion Batteries with Enhanced Reversible Capacity and Cyclic Performance. ACS Nano, 4 (2010), pp 3187-3194.

7. Croce, F.; Appetecchi, G. B.; Persi, L.; Scrosati, B., Nanocomposite polymer electrolytes for lithium batteries. Nature, 496 (1998), pp págs. 456-458.

8. Gong, F.; Xia, D.; Zhou, Q.; Liao, J.; Wu, M., Novel spherical cobalt/nickel mixedvanadates as high-capacity anodes in lithium ion batteries. J. Alloys Compd., 766 (2018), pp 442449.

9. $\quad$ Etacheri, V.; Seisenbaeva, G. A.; Caruthers, J.; Daniel, G.; Nedelec, J.-M.; Kessler, V. G.; Pol, V. G., Ordered Network of Interconnected $\mathrm{SnO}_{2}$ Nanoparticles for Excellent Lithium-Ion Storage. Adv. Energy Mater., 5 (2015), p 1401289.

10. Zhu, X.; Zhu, Y.; Murali, S.; Stoller, M. D.; Ruoff, R. S., Nanostructured reduced graphene oxide/ $\mathrm{Fe}_{2} \mathrm{O}_{3}$ composite as a high-performance anode material for lithium ion batteries. ACS Nano, 5 (2011), p 3333.

11. Kim, S. W.; Lee, H. W.; Muralidharan, P.; Seo, D. H.; Yoon, W. S.; Kim, D. K.; Kang, K., Electrochemical performance and ex situ analysis of $\mathrm{ZnMn}_{2} \mathrm{O}_{4}$ nanowires as anode materials for lithium rechargeable batteries. Nano Research, 4 (2011), pp 505-510.

12. Zhou, L.; Wu, H. B.; Zhu, T.; Lou, X. W., Facile preparation of $\mathrm{ZnMn}_{2} \mathrm{O}_{4}$ hollow microspheres as high-capacity anodes for lithium-ion batteries. J. Mater. Chem., 22 (2012), pp 827-829.

13. Yang, Y.; Zhao, Y.; Xiao, L.; Zhang, L., Nanocrystalline $\mathrm{ZnMn}_{2} \mathrm{O}_{4}$ as a novel lithiumstorage material. Electrochem. Commun., 10 (2008), pp 1117-1120.

14. Courtel, F. M.; Abu-Lebdeh, Y.; Davidson, I. J., $\mathrm{ZnMn}_{2} \mathrm{O}_{4}$ nanoparticles synthesized by a hydrothermal method as an anode material for Li-ion batteries. Electrochim. Acta, 71 (2012), pp 123-127.

15. Alfaruqi, M. H.; Rai, A. K.; Mathew, V.; Jo, J.; Kim, J., Pyro-Synthesis of Nanostructured Spinel $\mathrm{ZnMn}_{2} \mathrm{O}_{4} / \mathrm{C}$ as Negative Electrode for Rechargeable Lithium-Ion Batteries. Electrochim. Acta, 151 (2015), pp 558-564.

16. Zhu, S.; Shi, Y.; Chen, Q.; Chen, Z.; Bao, R.; Yang, C.; Hou, L.; Pang, G.; Yuan, C., Selfsacrificial template formation of ultrathin single-crystalline $\mathrm{ZnMn}_{2} \mathrm{O}_{4}$ nanoplates with enhanced Li-storage behaviors for Li-ion batteries. RSC Adv., 6 (2016), pp 2024-2027. 
17. Zhang, G.; Yu, L.; Wu, H. B.; Hoster, H. E.; Lou, X. W., Formation of $\mathrm{ZnMn}_{2} \mathrm{O}_{4}$ ball-inball hollow microspheres as a high-performance anode for lithium-ion batteries. Adv. Mater., 24 (2012), p 4609.

18. Liu, Y.; Bai, J.; Ma, X.; Li, J.; Xiong, S., Formation of quasi-mesocrystal $\mathrm{ZnMn}_{2} \mathrm{O}_{4}$ twin microspheres via an oriented attachment for lithium-ion batteries. J. Mater. Chem. A, 2 (2014), pp 14236-14244.

19. Xiao, L.; Yang, Y.; Yin, J.; Li, Q.; Zhang, L., Low temperature synthesis of flower-like $\mathrm{ZnMn}_{2} \mathrm{O}_{4}$ superstructures with enhanced electrochemical lithium storage. J. Power Sources, 194 (2009), pp 1089-1093.

20. Yuan, J.; Chen, C.; Hao, Y.; Zhang, X.; Agrawal, R.; Zhao, W.; Wang, C.; Yu, H.; Zhu, X.; Yu, Y.; Xiong, Z.; Xie, Y., Fabrication of three-dimensional porous $\mathrm{ZnMn}_{2} \mathrm{O}_{4}$ thin films on Ni foams through electrostatic spray deposition for high-performance lithium-ion battery anodes. J. Alloys Compd., 696 (2017), pp 1174-1179.

21. Zhong, M.; Yang, D.; Xie, C.; Zhang, Z.; Zhou, Z.; Bu, X. H., Yolk - Shell $\mathrm{MnO} @ \mathrm{ZnMn}_{2} \mathrm{O}_{4} / \mathrm{N}$ - C Nanorods Derived from a - $\mathrm{MnO}_{2} / \mathrm{ZIF}-8$ as Anode Materials for Lithium Ion Batteries. Small, 12 (2016), pp 5564-5571.

22. Peng, S.; Li, L.; Hu, Y.; Srinivasan, M.; Cheng, F.; Chen, J.; Ramakrishna, S., Fabrication of Spinel One-Dimensional Architectures by Single-Spinneret Electrospinning for Energy Storage Applications. ACS Nano, 9 (2015), pp 1945-1954.

23. Xiang, J. Y.; Tu, J. P.; Zhang, L.; Zhou, Y.; Wang, X. L.; Shi, S. J., Self-assembled synthesis of hierarchical nanostructured $\mathrm{CuO}$ with various morphologies and their application as anodes for lithium ion batteries. J. Power Sources, 195 (2010), pp 313-319.

24. Saravanan, K.; Balaya, P.; Reddy, M. V.; Chowdari, B. V. R.; Vittal, J. J., Morphology controlled synthesis of $\mathrm{LiFePO}_{4} / \mathrm{C}$ nanoplates for Li-ion batteries. Energ. Environ. Sci., 3 (2010), pp 457-463.

25. Wang, N.; Ma, X.; Xu, H.; Chen, L.; Yue, J.; Niu, F.; Yang, J.; Qian, Y., Porous $\mathrm{ZnMn}_{2} \mathrm{O}_{4}$ microspheres as a promising anode material for advanced lithium-ion batteries. Nano Energy, 6 (2014), pp 193-199.

26. Chen, X.; Zhang, Y.; Lin, H.; Xia, P.; Cai, X.; Li, X.; Li, X.; Li, W., Porous $\mathrm{ZnMn}_{2} \mathrm{O}_{4}$ nanospheres: Facile synthesis through microemulsion method and excellent performance as anode of lithium ion battery. J. Power Sources, 312 (2016), pp 137-145.

27. Zhong, X.; Wang, X.; Wang, H.; Yang, Z.; Jiang, Y.; Li, J.; Tian, Z., Ultrahighperformance mesoporous $\mathrm{ZnMn}_{2} \mathrm{O}_{4}$ microspheres as anode materials for lithium-ion batteries and their in situ Raman investigation. Nano Research, 11 (2018), pp 3814-3823.

28. Chen, S.; Yao, M.; Wang, F.; Wang, J.; Zhang, Y.; Wang, Y., Facile microemulsion synthesis of mesoporous $\mathrm{ZnMn}_{2} \mathrm{O}_{4}$ submicrocubes as high-rate and long-life anodes for lithium ion batteries. Ceram. Int., 45 (2019), pp 5594-5600.

29. Zhang, L.; Zhu, S.; Cao, H.; Hou, L.; Yuan, C., Hierarchical Porous $\mathrm{ZnMn}_{2} \mathrm{O}_{4}$ Hollow Nanotubes with Enhanced Lithium Storage toward Lithium-Ion Batteries. Chemistry - A European Journal, 21 (2015), pp 10771-10777.

30. Zhu, S.; Chen, Q.; Yang, C.; Zhang, Y.; Hou, L.; Pang, G.; He, X.; Zhang, X.; Yuan, C., Biomorphic template-engaged strategy towards porous zinc manganate micro-belts as a competitive anode for rechargeable lithium-ion batteries. Int. J. Hydrogen Energy, 42 (2017), pp 14154-14165.

31. Zhang, Y.; Wang, Z.; Zaman, F. u.; Zhao, Z.; Sun, X.; Zhang, J.; Hou, L.; Yuan, C., Hollow mesoporous hetero- $\mathrm{ZnO} / \mathrm{ZnMnO}_{3}$ microspheres: template-free formation process and enhanced 
lithium storage capability towards Li-ion batteries as a competitive anode. J. Mater. Chem. A, 7 (2019), pp 3264-3277.

32. Zhang, Y.; Zhang, Y.; Guo, C.; Tang, B.; Wang, X.; Bai, Z., Porous $\mathrm{ZnMn}_{2} \mathrm{O}_{4}$ nanowires as an advanced anode material for lithium ion battery. Electrochim. Acta, 182 (2015), pp 11401144 .

33. Sieron, L.; Bukowska-Strzyzewska, M., catena-Poly[[bis(benzimidazole-N3)copper(II)][mu]-suberato-O,O':O",O"'] and catena-poly[[[bis(benzimidazole-N3)copper(II)]-[mu]-sebacatoO,O':O",O"'] dihydrate]. Acta Cryst. C, 55 (1999), pp 1230-1234.

34. Chan, Y.-N.; Zhao, H.-K.; Wang, X.-G.; Zhao, X.-J., catena-Poly[[bis(N,Ndimethylformamide)manganese(II)]-di-[mu]2-oxalato]. Acta Cryst. E, 63 (2007), pp m70-m72. 35. Lee, J. E.; Lee, H.-I., catena-Poly[[bis-(N,N-dimethyl-formamide- $\kappa$ O)zinc]- $\mu$ (2)oxalato- $\mathrm{k}(4) \mathrm{O}(1), \mathrm{O}(2): \mathrm{O}\left(1^{\prime}\right.$ ), O (2' )]. Acta Cryst. E: Structure Reports Online, 67 (2011), pp m1172-m1172.

36. Lai, J.-Y.; Huang, S.-J.; Chen, S.-H., Poly(methyl methacrylate)/(DMF/metal salt) complex membrane for gas separation. J. Membr. Sci., 74 (1992), pp 71-82.

37. Othman, M. F.; Anuar, N.; Ad Rahman, S.; Ahmad Taifuddin, N. A., Cocrystal Screening of Ibuprofen with Oxalic Acid and Citric Acid via Grinding Method. IOP Conf. Series: Mater. Sci. Eng., 358 (2018), p 012065.

38. Stalhandske, C. M. V.; Mink, J.; Sandström, M.; Pápai, I.; Johansson, P., Vibrational spectroscopic and force field studies of N,N-dimethylthioformamide, N,N-dimethylformamide, their deuterated analogues and bis(N,N-dimethylthioformamide)mercury(II) perchlorate. Vib. Spectrosc., 14 (1997), pp 207-227.

39. Jacob, M. M. E.; Arof, A. K., FTIR studies of DMF plasticized polyvinyledene fluoride based polymer electrolytes. Electrochim. Acta, 45 (2000), pp 1701-1706.

40. Starkey, S. R.; Frech, R., Plasticizer interactions with polymer and salt in propylene carbonate-poly(acrylonitrile)-lithium triflate. Electrochim. Acta, 42 (1997), pp 471-474.

41. Xiao, T.; Yuan, H.; Ma, Q.; Guo, X.; Wu, Y., An approach for in situ qualitative and quantitative analysis of moisture adsorption in nanogram-scaled lignin by using micro-FTIR spectroscopy and partial least squares regression. Int. J. Biol. Macromol., 132 (2019), pp 11061111.

42. $\quad$ Ren, N.; Jiu, H.; Jiang, L.; Zhang, Q.; Yu, S.; Gao, Y.; Gao, Z.; Zhang, L., Facile synthesis of hierarchical porous $\mathrm{ZnMn}_{2} \mathrm{O}_{4}$ rugby-balls on $\mathrm{Ni}$ foam for lithium-ion batteries with enhanced electrochemical properties. J. Alloys Compd., 740 (2018), pp 28-35.

43. Fan, B.; Hu, A.; Chen, X.; Zhang, S.; Tang, Q.; Wang, J.; Deng, W.; Liu, Z.; Xiao, K., Hierarchical Porous $\mathrm{ZnMn}_{2} \mathrm{O}_{4}$ Microspheres as a High-Performance Anode for Lithium-Ion Batteries. Electrochim. Acta, 213 (2016), pp 37-45.

44. Liu, Y.; Lv, B.; Li, P.; Chen, Y.; Gao, B.; Lin, B., Biotemplate-assisted hydrothermal synthesis of tubular porous $\mathrm{Co}_{3} \mathrm{O}_{4}$ with excellent charge-discharge cycle stability for supercapacitive electrodes. Mater. Lett., (2017).

45. Zhang, P.; Li, X.; Zhao, Q.; Liu, S., Synthesis and optical property of one-dimensional spinel $\mathrm{ZnMn}_{2} \mathrm{O}_{4}$ nanorods. Nanoscale Res. Lett., 6 (2011), pp 1-8.

46. Kim, J. G.; Lee, S. H.; Kim, Y.; Kim, W. B., Fabrication of free-standing $\mathrm{ZnMn}_{2} \mathrm{O}_{4}$ mesoscale tubular arrays for lithium-ion anodes with highly reversible lithium storage properties. ACS Appl. Mater. Interfaces, 5 (2013), p 11321. 
47. Rong, H.; Xie, G.; Cheng, S.; Zhen, Z.; Jiang, Z.; Huang, J.; Jiang, Y.; Chen, B.; Jiang, Z. J., Hierarchical porous $\mathrm{ZnMn}_{2} \mathrm{O}_{4}$ microspheres architectured with sub-nanoparticles as a high performance anode for lithium ion batteries. J. Alloys Compd., 679 (2016), pp 231-238.

48. Cao, X.; Yan, W.; Jin, C.; Tian, J.; Ke, K.; Yang, R., Surface modification of $\mathrm{MnCo}_{2} \mathrm{O}_{4}$ with conducting polypyrrole as a highly active bifunctional electrocatalyst for oxygen reduction and oxygen evolution reaction. Electrochim. Acta, 180 (2015), pp 788-794.

49. Wang, C.; Wang, H.; Chen, Q.; Ren, B.; Duan, R.; Guan, R., Synchronous regulation of morphology and crystal phase of $\mathrm{TiO} 2$ via a facile green hydrothermal approach and their photocatalytic activity. Mater. Res. Bull., 109 (2019), pp 90-97.

50. BoopathiRaja, R.; Parthibavarman, M.; Nishara Begum, A., Hydrothermal induced novel $\mathrm{CuCo}_{2} \mathrm{O}_{4}$ electrode for high performance supercapacitor applications. Vacuum, 165 (2019), pp 96-104.

51. Eng, A. Y. S.; Cheong, J. L.; Lee, S. S., Controlled synthesis of transition metal disulfides $\left(\mathrm{MoS}_{2}\right.$ and $\left.\mathrm{WS}_{2}\right)$ on carbon fibers: Effects of phase and morphology toward lithium-sulfur battery performance. Appl. Mater. Today, 16 (2019), pp 529-537.

52. Zou, F.; Hu, X.; Li, Z.; Qie, L.; Hu, C.; Zeng, R.; Jiang, Y.; Huang, Y., MOF-Derived Porous $\mathrm{ZnO} / \mathrm{ZnFe}_{2} \mathrm{O}_{4} / \mathrm{C}$ Octahedra with Hollow Interiors for High-Rate Lithium-Ion Batteries. Adv. Mater., 26 (2014), pp 6622-6628.

53. Zhang, G.; Yu, L.; Wu, H. B.; Hoster, H. E.; Lou, X. W., Formation of $\mathrm{ZnMn}_{2} \mathrm{O}_{4}$ Ball-inBall Hollow Microspheres as a High-Performance Anode for Lithium-Ion Batteries. Adv. Mater., 24 (2012), pp 4609-4613.

54. Yao, W.; Xu, J.; Wang, J.; Luo, J.; Shi, Q.; Zhang, Q., Chemically Integrated Multiwalled Carbon Nanotubes/Zinc Manganate Nanocrystals as Ultralong-Life Anode Materials for LithiumIon Batteries. ACS Sustain. Chem. Eng., 3 (2015), pp 2170-2177.

55. Li, P.; Liu, J.; Liu, Y.; Wang, Y.; Li, Z.; Wu, W.; Wang, Y.; Yin, L.; Xie, H.; Wu, M., Three-dimensional $\mathrm{ZnMn}_{2} \mathrm{O}_{4}$ /porous carbon framework from petroleum asphalt for high performance lithium-ion battery. Electrochim. Acta, 180 (2015), pp 164-172.

56. Chan, C. K.; Ruffo, R.; Hong, S. S.; Cui, Y., Surface chemistry and morphology of the solid electrolyte interphase on silicon nanowire lithium-ion battery anodes. J. Power Sources, 189 (2009), pp 1132-1140.

57. Wu, H.; Chan, G.; Choi, J. W.; Ryu, I.; Yao, Y.; McDowell, M. T.; Lee, S. W.; Jackson, A.; Yang, Y.; Hu, L.; Cui, Y., Stable cycling of double-walled silicon nanotube battery anodes through solid-electrolyte interphase control. Nat. Nanotechnol., 7 (2012), pp 310-315.

58. Li, G.; Wang, Y.; Yang, L.; Ma, W.; Wang, M., In Situ Synthesis of $\mathrm{ZnMn}_{2} \mathrm{O}_{4}-\mathrm{ZnO}-\mathrm{C}$ and $\mathrm{ZnMn}_{2} \mathrm{O}_{4}-\mathrm{C}$ Nanohybrids as High Performance Lithium-Ion Battery Anodes. Eur. J. Inorg. Chem., 2014 (2014), pp 845-851.

59. Zhang, T.; Gao, Y.; Yue, H.; Qiu, H.; Guo, Z.; Wei, Y.; Wang, C.; Chen, G.; Zhang, D., Convenient and high-yielding strategy for preparing nano- $\mathrm{ZnMn}_{2} \mathrm{O}_{4}$ as anode material in lithiumion batteries. Electrochim. Acta, 198 (2016), pp 84-90.

60. Dang, W.; Wang, F.; Ding, Y.; Feng, C.; Guo, Z., Synthesis and electrochemical properties of $\mathrm{ZnMn}_{2} \mathrm{O}_{4}$ microspheres for lithium-ion battery application. J. Alloys Compd., 690 (2017), pp 72-79.

61. Feng, C.; Wang, W.; Chen, X.; Wang, S.; Guo, Z., Synthesis and electrochemical properties of $\mathrm{ZnMn}_{2} \mathrm{O}_{4}$ anode for lithium-ion batteries. Electrochim. Acta, 178 (2015), pp 847855. 
62. Zou, Y.; Zhang, W.; Chen, N.; Chen, S.; Xu, W.; Cai, R.; Brown, C. L.; Yang, D.; Yao, X., Generating Oxygen Vacancies in $\mathrm{MnO}$ Hexagonal Sheets for Ultralong Life Lithium Storage with High Capacity. ACS Nano, 13 (2019), pp 2062-2071.

63. Wu, B.; Xie, Y.; Meng, Y.; Qian, C.; Chen, Y.; Yuan, A.; Guo, X.; Yang, H.; Wan, S.; Lin, S., Construction of unique heterogeneous cobalt-manganese oxide porous microspheres for the assembly of long-cycle and high-rate lithium ion battery anodes. J. Mater. Chem. A, 7 (2019), pp 6149-6160.

64. Dang, W.; Wang, F.; Ding, Y.; Feng, C.; Guo, Z., Synthesis and electrochemical properties of $\mathrm{ZnMn}_{2} \mathrm{O}_{4}$ microspheres for lithium-ion battery application. J. Alloys Compd., 690 (2016), pp 72-79.

65. Zeng, X.; Shi, L.; Li, L.; Yang, J.; Cheng, X.; Gao, M., The preparation of flowerlike $\mathrm{ZnMn}_{2} \mathrm{O}_{4}$ microspheres assembled with porous nanosheets and their lithium battery performance as anode materials. RSC Adv., 5 (2015), pp 70379-70386.

66. Wang, L.; Yue, S.; Zhang, Q.; Zhang, Y.; Li, Y. R.; Lewis, C. S.; Takeuchi, K. J.; Marschilok, A. C.; Takeuchi, E. S.; Wong, S. S., Morphological and Chemical Tuning of HighEnergy-Density Metal Oxides for Lithium Ion Battery Electrode Applications. ACS Energy Letters, 2 (2017), pp 1465-1478.

67. Jing, M.; Li, F.; Chen, M.; Long, F.; Wu, T., Binding ZnO nanorods in reduced graphene oxide via facile electrochemical method for Na-ion battery. Appl. Surf. Sci., 463 (2019), pp 986993.

68. Park, J.; Ju, J.-B.; Choi, W.; Kim, S.-O., Highly reversible ZnO@ZIF-8-derived nitrogendoped carbon in the presence of fluoroethylene carbonate for high-performance lithium-ion battery anode. J. Alloys Compd., 773 (2019), pp 960-969. 